*aMIS View/Print Document Cover Sheet

This document was retrieved from the Boeing ISEARCH System.

Accession \#: D196054472

Document \#: SD-WM-ER-422

Title/Desc:

TANK 241BY108 HEADSPACE GAS \& VAPOR

CHARACTERIZATION RESULTS FOR SAMPLES COLLECTED IN $3 / 1994 \& 10 / 1994$ 


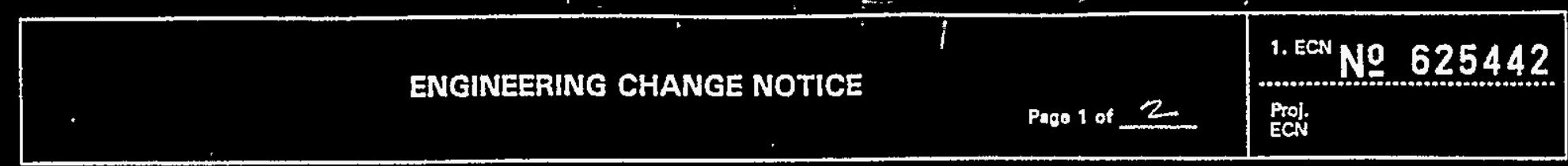

\begin{tabular}{|c|c|c|c|c|c|c|}
\hline \multirow{3}{*}{$\begin{array}{l}\text { 2. ECN Category } \\
\text { (mark one) } \\
\text { Supplemental } \\
\text { Direct Revision } \\
\text { Change ECN } \\
\text { Temporary } \\
\text { Standby } \\
\text { Supersedure } \\
\text { Cancel/Void }\end{array}$} & \multirow{3}{*}{ 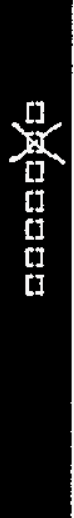 } & \multicolumn{2}{|c|}{$\begin{array}{l}\text { 3. Originator's Name, Organization, MSIN, } \\
\text { and Tel ephone No. } \\
\text { D. R. BRATZEL, 75640, S7-21, } \\
\text { 373-3579 }\end{array}$} & \multicolumn{2}{|c|}{$\begin{array}{l}\text { 3a. USQ Required? } \\
\text { [] Yes [X] No }\end{array}$} & $\begin{array}{l}\text { 4. Date } \\
09 / 27 / 95\end{array}$ \\
\hline & & \multicolumn{2}{|c|}{$\begin{array}{l}\text { 5. Project Title/No./Work Order No. } \\
\text { TANK 241-BY-108.HEADSPACE GAS } \\
\text { AND VAPOR CHARACTERIZATION } \\
\text { RESULTS FOR SAMPLES COLLECTED } \\
\text { IN MARCH } 1994 \text { AND OCTOBER } 1994\end{array}$} & \multicolumn{2}{|c|}{$\begin{array}{l}\text { 6. Bldg./Sys./Fac. No. } \\
2704 \mathrm{HV} / 200 \mathrm{E}\end{array}$} & $\begin{array}{l}\text { 7. Approval Designator } \\
\qquad N / A\end{array}$ \\
\hline & & \multicolumn{2}{|c|}{$\begin{array}{l}\text { 8. Document Numbers changed by this ECN } \\
\text { (includes sheet no. and rev.) } \\
\text { WHC-SD-WM-ER-422 REV } 22,\end{array}$} & \multicolumn{2}{|c|}{$\begin{array}{l}\text { 9. Related ECN No(s). } \\
6 / 95 \quad \text { N/A }\end{array}$} & 10. Related PO No. \\
\hline \multirow{2}{*}{\multicolumn{2}{|c|}{$\begin{array}{l}\text { 11a. Modification Work } \\
\text { [] Yes (fill out Blk. } \\
\text { [X] No (NA Blks. 11b, } \\
11 \mathrm{c}, 11 \mathrm{~d} \text { ) }\end{array}$}} & \multirow[t]{2}{*}{$\begin{array}{l}\text { 11b. Work Package } \\
\text { No. } \\
\text { N/A }\end{array}$} & \multirow{2}{*}{\multicolumn{2}{|c|}{$\begin{array}{l}\text { 11c. Modificátion Work Complete } \\
\text { N/A }\end{array}$}} & \multicolumn{2}{|c|}{$\begin{array}{l}\text { 11d. Restored to Original Condi- } \\
\text { tion (Temp. or Standby ECN only) } \\
\text { N/A }\end{array}$} \\
\hline & & & & & $\operatorname{cog}$. & neer $s$ \\
\hline
\end{tabular}

12. Description of Change

Title change and complete rewrite.

13a. Justification (mark one)

Criteria Change [X] Design Improvement [] Environmental [] Facility Deactivation [] As-Found [] Facilitate Const [] Const. Error/Omission [] Design Error/Omission []

13b. Justification Details

Complete rewrite which includes all vapor sampling events to date and data qualification.

14. Distribution (include name, MSIN, and no. of copies)

See attached Distribution sheet 


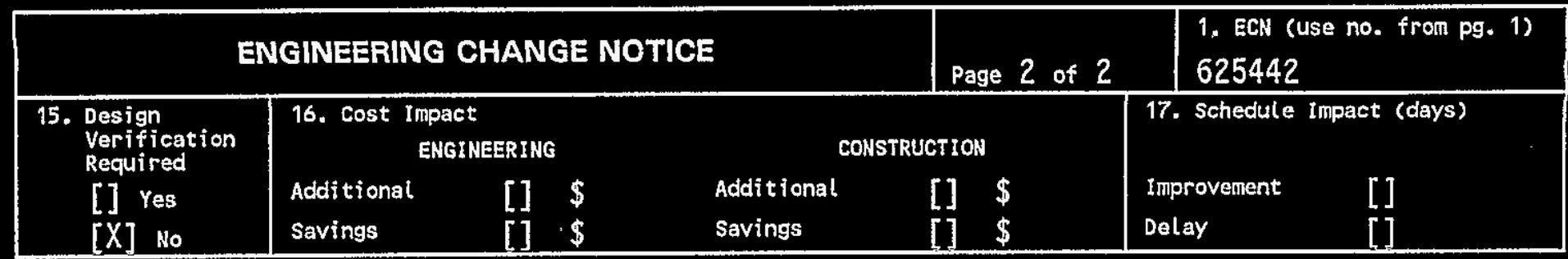

18. Change Impact Review: Indicate the related documents (other than the engineering documents identified on Side 1) that will be affected by the change described in Block 12 . Enter the affected document number in Block 19.

SDD/DD
Functional Design Criteria
Operating Specification
Criticality Specification
Conceptual Design Report
Equipment Spec.
Const. Spec.
Procurement Spec.
Vendor Information
OM Manual
FSAR/SAR
Safoty Equipment List
Radiation Work Permit
Environmental Impact Statement
Environmental Report
Environmental Pormit

19. Other Affected Documents: (NorE: Documents listed below will not be revised by this ECN.) Signatures below indicate that the signing organization has been notified of other affected documents listed below. Document Number/Revision

[] Seismic/Stress Analysis

[]

[]

[]

[]

[]

[]

[]

[]

[]

[]

[]

[]

[]

[]

[1]
Stress/Design Report

Interface Control Drawing

Calibration Procedure

Installation Procedure

Maintenance Procedure

Engineering Procedure

Operating Instruction

Operating Procedure

Operational Safoty Requirement

IEFD Drawing

Cell Arrangement Drawing

Essential Material Specification

Fac. Proc. Samp. Schedulo

Inspection Plan

Inventory Adjustment Request

[] Tank Calibration Manual

[]

[]

[]

[]

[]

[]

[]

[]

[]

[]

[]

[]

[]

[]

Health Physics Procedure

Spares Multiplo Unit Listing

Test Procedures/Specification

Component Index

ASME Coded item

Human Factor Consideration .

Computer Software

Electric Cirsuit Schedule

ICRS Procedure

Process Control Manual/Plan

Process Flow Chart

Purchase Requisition

Tickler Filo

Document Number Revision

20. Approvals

\section{Signature} OPERATIONS AND ENGINEERING

Cog. Eng. D. R. Bratzel DRB

Cog. Mgr. T. J. Kelley

QA

Safety

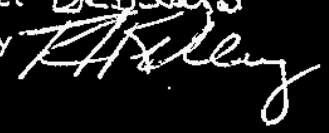

Environ.

other

Proj.

Proj.

Proj.

Proj.
Document Number/Revision

]




\section{RELEASE AUTHORIZATION}

Document Number: WHC-SD-WM-ER-422, REV 2

Document Title: Tank 241-BY-108 Headspace Gas and Vapor

Characterization Results for Samples Collected in March 1994 and October 1994

Release Date: $\quad 9 / 26 / 95$

is.

This document was reviewed following the procedures described in WHC-CM-3-4 and is:

APPROVED FOR PUBLIC RELEASE

WHC information Release Administration Specialist:
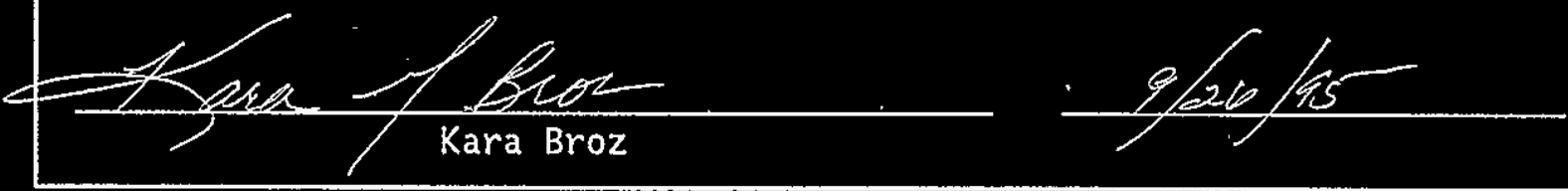

TRADEMARK DISCLAIHER. Reference here in to any specific commercial product, process, or service by trade name, trademark, manufacturer, or otherwise, does not necessarily constitute or imply its endorsement, recommendation, or favoring by the United States Government or any agency thereof or its contractors or subcontractors.

This report has been reproduced from the best available copy. Availabie in paper copy. Printed in the United States of America. To obtain copies of this report, contact:

Westinghouse Hanford Company - Document Control Services

P.0. Box 1970, Mailstop H6-08, Richland, WA 99352

Telephone: (509) 372-2420; Fax: (509) 376-4989 

2. Title

TANK 241-BY-108 HEADSPACE GAS AND VAPOR CHARACTERIZATION RESULTS FOR SAMPLES COLLECTED IN MARCH 1994 AND OCTOBER 1994

5. Key Words

CHARACTERIZATION OBJECTIVES, TANK HEADSPACE, SAMPLING EVENT, INORGANIC GASES, ORGANIC VAPORS

\section{Number}

NHC-SD-NH-ER-422
4. Rev No.

2
6. Author

Name:

D. R. BRATZEL

$\frac{D P B}{\text { Signature }}$ atgh $9 / 25 / 05$ Organization/Charge code $75640 / N 4 A B 1$

\section{Abstract}

Significant changes have been made to all of the original vapor characterization reports. This report documents specific headspace gas and vapor characterization results for all vapor sampling events to date. In addition, changes have been made to the original vapor reports to qualify the data based on quality assurance issues associated with the performing laboratories.

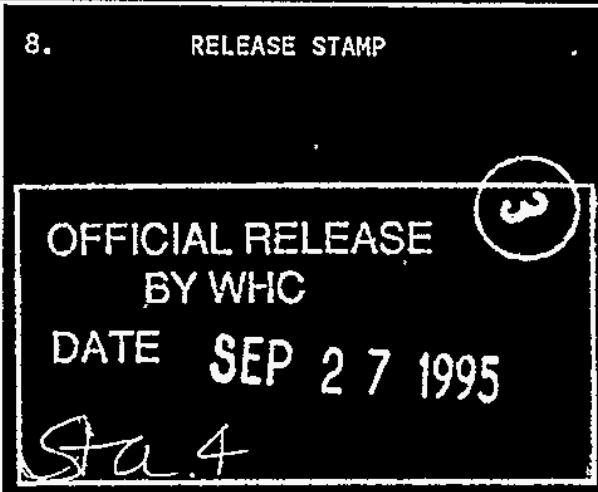



(2) Title

TANK 241-BY-108 HEADSPACE GAS AND VAPOR CHARACTERIZATION RESULTS FOR SAMPLES COLLECTED IN MARCH 1994 AND OCTOBER 1994

\begin{tabular}{|c|c|c|c|c|}
\hline \multirow{2}{*}{ (3) } & \multirow{2}{*}{ Revision } & \multirow{2}{*}{ (4) Description of Change - Replace, Add, and Delete Pages } & \multicolumn{2}{|c|}{ Authorized for Release } \\
\hline & & & (5) Cog. Engr. & (6) Cog. Mgr. \\
\hline & 0 & $\begin{array}{l}\text { (7) WHC-SD-WM-ER-422, REV. 0, EDT } 159093 \\
\text { May 31, } 1995\end{array}$ & & \\
\hline & 1 & $\begin{array}{l}\text { Made editorial changes and added } \\
\text { information in organic vapor chapter. ECN } \\
623.545\end{array}$ & & \\
\hline & $2 \mathrm{RS}$ & $\begin{array}{l}\text { Complete revision and title change. ECN } \\
625442\end{array}$ & & \\
\hline & & 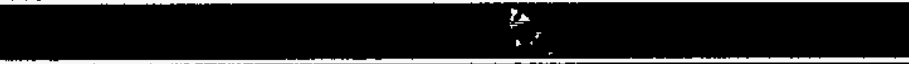 & J & 7 \\
\hline & & : & & \\
\hline & & & & \\
\hline & & & & . \\
\hline & & & & \\
\hline & & & & \\
\hline & & & & \\
\hline & & $\cdot$ & & \\
\hline & & & & \\
\hline & & & & \\
\hline & & & & \\
\hline & & & & \\
\hline
\end{tabular}


$\not$ 


\title{
Tank 241-BY-108 Headspace Gas and Vapor Characterization Results for Samples Collected in March 1994 and October 1994
}

\author{
J. L. Huckaby
}

Pacific Northwest Laboratories

D. R. Bratzel

Westinghouse Hanford Company

Date Published

September 1995

Prepared for the U.S. Department of Energy Office of Environmental Restoration and Waste Management

$\begin{array}{ll}\text { Westinghouse } & \text { P.O Box } 1970 \\ \text { Hanford Company } & \text { Richland, Washington }\end{array}$

Management and Operations Contractor for the 


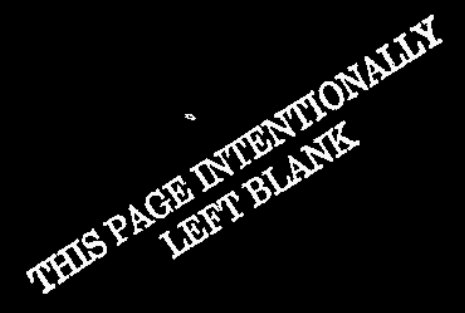




\section{Contents}

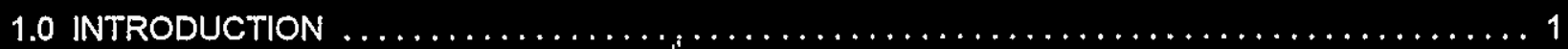

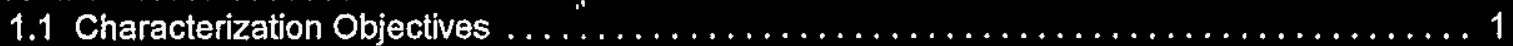

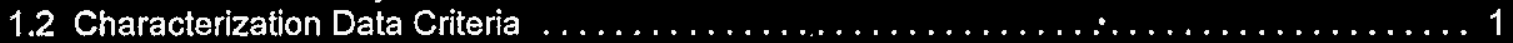

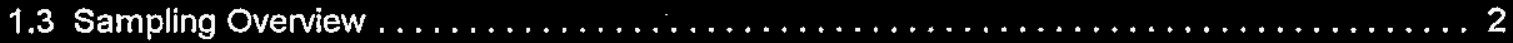

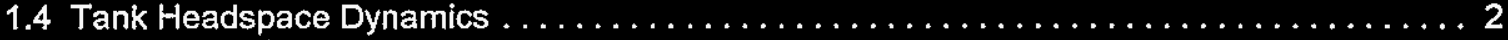

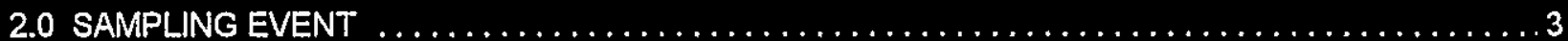

2.1 March 1994 in Situ Sampling Event ............................... 3

2.2 October 1994 Vapor Sampling System Sampling Event ..................... 3

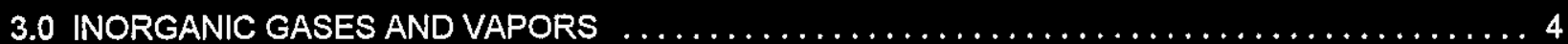

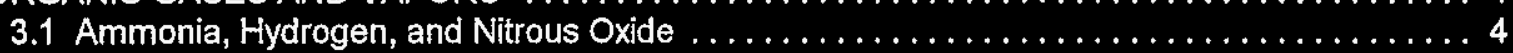

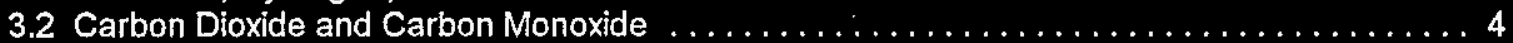

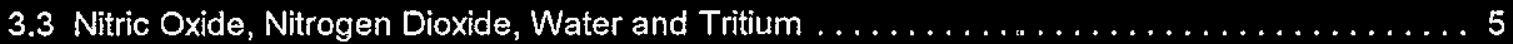

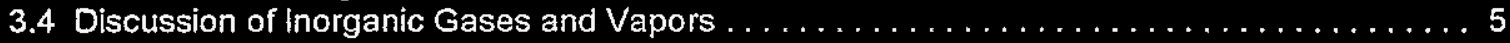

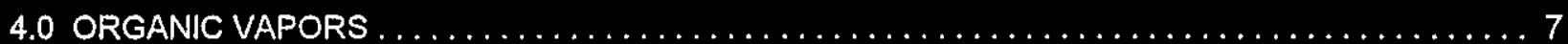

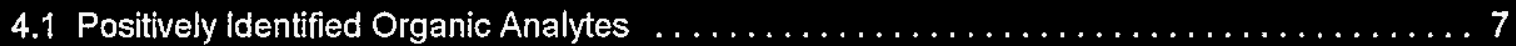

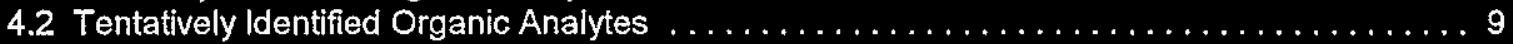

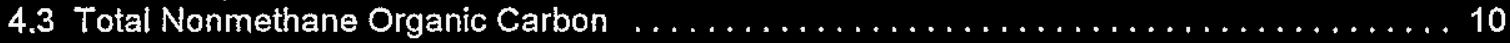

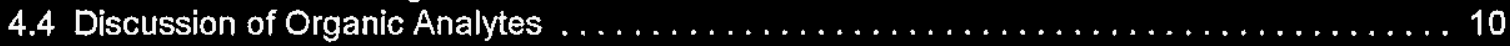

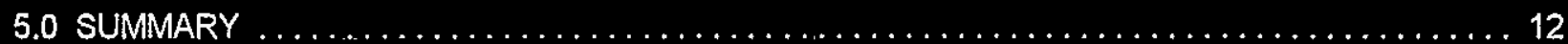

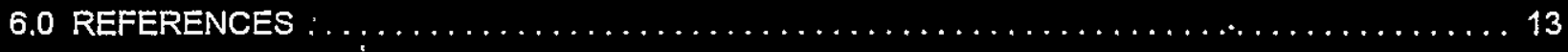

Acronyms and Abbreviations

$\begin{array}{ll}\text { CES } & \text { consensus exposure standard } \\ \text { EPA } & \text { Environmental Protection Agency } \\ \text { GC } & \text { gas chromatograph } \\ \text { GC/MS } & \text { gas chromatograph/mass spectrometer } \\ \text { ISS } & \text { in situ sampling } \\ \text { LFL } & \text { lower flammability limit } \\ \text { MS } & \text { mass spextrometer } \\ \text { NFPA } & \text { National Fire Protection Association } \\ \text { NPH } & \text { normal paraffinic hydrocarbon } \\ \text { OCIST } & \text { Oregon Graduate Institute of Science and Technology } \\ \text { ORNL. } & \text { Oak Ridge National Laboratory } \\ \text { PNL } & \text { Pacific Northwest Laboratory } \\ \text { ppmv } & \text { parts per million by volume, } 1 \text { ppmv }=10^{-4} \text { vol\% } \\ \text { TNMOC } & \text { total nonmethane organic carbon } \\ \text { TST } & \text { triple sorbent trap } \\ \text { vol\% } & \text { percent by volume, } 1 \text { vol\% }=10,000 \mathrm{ppmv} \\ \text { VSS } & \text { vapor sampling system } \\ \text { WHC } & \text { Westinghouse Hanford Company }\end{array}$

\section{Acknowledgements}

The author wishes to thank Chris Simonen for her work verifying data and generating tables, and Shas Mattigod for his help with the construction and reviews of this document. 


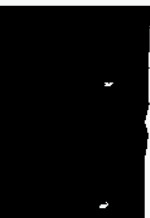


WHC-SD-WM-ER-422 REV. 2

Tank 241-BY-108 Headspace Gas and Vapor Characterization Results

for Samples Collected in March 1994 and October 1994

\subsection{INTRODUCTION}

\subsection{Characterization Objectives}

Tank BY -108 headspace gas and vapor samples were collected and analyzed to help determine the potential risks of fugitive emissions to tank farm workers. The drivers and objectives of waste tank headspace sampling and analysis are discussed in Program Plan for the Resolution of Tank Vapor Issues (Osborne and Huckaby 1994). This report primarily discusses results from the October 1994 sampling event, but also includes selected results of the March 1994 sampling event. The tank BY-108 headspace was sampled in March 1994 in accordance with Safety Assessment for Gas Sampling All Ferrocyanide Tanks (Farley 1991), and in October 1994 in accordance with Data Quality Objectives for Generic In-Tank Health and Safety Issue Resolution (Osborne et al. 1994).

\subsection{Characterization Data Criteria}

Data Quality Objectives for Generic In-Tank Health and Safety Issue Resolution describes parameters for data collection to ensure appropriate conclusions can be drawn from the data. Tank headspace characterization data were collected to heip in the evaluation of 1) headspace flammability, and 2) identification and quantification of compounds of toxicological concern.

Single Shell Tank Interim Operational Safety Requirements (Dougherty 1995) specifies that combustible constituents in tank headspaces be maintained below $25 \%$ of the lower flammability limit (LFL). This essentially agrees with National Fire Protection Association requirements that combustible concentrations be maintained at or below $25 \%$ of the LFL (NFPA 1992). Current governing operating specifications for Watchlist tanks, such as tank BY-108, specify that combustible constituents be maintained at or below 20 $\%$ of the LFL (WHC 1995a).

Headspace characterization data are used by Westinghouse Hanford Company (WHC) Tank Waste Remediation Systems Industrial Hygiene as source term data in the industrial hygiene strategy to protect workers from tank fugitive emissions. Because selection of worker protective equipment must be based on industrial hygiene monitoring of the work place and not on source term data (29 CFR 1910.120), tank headspace characterization data can not be used for this purpose. Furthermore, because there are mechanisms by which headspace constituents can be either diluted or concentrated as they are released to the atmosphere, the headspace characterization data should not be considered to be representative of emissions at the point of emission.

These statements notwithstanding, the data quality objectives document specifies that the industrial hygiene group be advised if constituents with toxicological properties exceed $50 \%$ of the appropriate consensus exposure standard (CES) for non-carcinogens, or $10 \%$ of the appropriate CES for carcinogens. A CES is defined as the most stringent of known regulatory or recommended toxicological values for the workplace (Osborne et al. 1994). 
WHC-SD-WM-ER-422 REV. 2

\subsection{Sampling Overview}

Tank BY-108 was vapor sampled in March 1994 using the in situ sampling (ISS) method, and again in October 1994 using the more robust vapor sampling system (VSS) method. Unfortunately, the ISS event sorbent trap samples were radiologically contaminated, and were never analyzed (Huckaby et al. 1995). Furthermore, there are discrepancies between results from the ISS and VSS methods that are not understood (Huckaby 1994a), and until the ISS method has been validated and the discrepancies resoived, results from early ISS events should be considered suspect.

Nevertheless, a brief description of the ISS event and the total nonmethane organic carbon (TNMOC) measurement from the March 1994 ISS event are presented below, because this analysis was not performed on samples from the VSS event. All other results presented here are from the October 1994 VSS sampling event.

Samples collected are thought to have been representative of the tank headspace when the tank was sampled (Meacham et al. 1995), and sample analyses were designed to provide a reasonably accurate and complete characterization of the significant headspace constituents. No assessment has been made of how the tank BY-108 headspace composition changes with time, though studies of tank C-103 suggest that composition changes probably occur very slowly in passively ventilated tanks, such as tank BY-108 (Huckaby and Story 1994).

\subsection{Tank Headspace Dynamics}

Tank BY-108 is the second tank in a 3-tank cascade with tanks BY-107 and BY-109. It is connected to tanks BY-107 and BY-109 via a 7.4-cm (2.9-in.) inside diameter, 7.6-m (25-ft) long underground cascade lines. Since these cascade lines connect the headspaces of these tanks, gases and vapors originating from the wastes in tank BY-107 or BY-109 may be transferred to tank BY-108 (unless the cascade lines are obstructed).

The cascade of tanks BY-107, BY-108, and BY-109 is passively ventilated, which means that the tanks are allowed to exhale air, waste gases, and vapors as the barometric pressure falls, and inhale ambient air as the barometric pressure rises. Each of these tanks has its own filtered breather riser. Barometric pressure typically rises and falls on a diumal cycle, producing an average daily exchange of air equal to about $0.46 \%$ of each tank headspace (Huckaby 1994b). Changes in the concentrations of tank headspace constituents due to barometric pressure changes are consequently very slow. 


\subsection{SAMPLING EVENT}

\subsection{March 1994 In Situ Sampling Event}

Tank BY-108 was sampled using ISS methods on March 24, 1994 by WHC Sampling and Mobile Laboratories. This sampling was conducted to satisfy requirements of Safety Assessment for Gas Sampling All Ferrocyanide Tanks (Farley 1991). Samples were collected from a point approximately 7.9 $\mathrm{m}$ below the top of the flange on riser 1, between 10:00 a.m. and 12:30 p.m. Though the sorbent traps were physically lowered down into the headspace to minimize loss of analytes through condensation, adsorption, or absorption by condensate, the SUMMA ${ }^{\mathrm{TM}}$ canister samples were collected using unheated transfer tubing.

Huckaby et al. (1995) give a general description of the ISS method and equipment. Pingel (1994a) provides field sampling information for the tank BY-108 March 1994 ISS event. In addition to the TNMOC measurement results presented below, McVeety et al. (1995a) and Rasmussen (1994a) provide other sample analysis results.

\subsection{October 1994 Vapor Sampling System Sampling Event}

Headspace gas and vapor samples were collected from tank BY-108 using the VSS on October 27, 1994 by WHC Sampling and Mobile Laboratories, (WHC 1995b). Sample collection and analysis were performed as directed by Tank 241-BY-108 Tank Characterization Plan (Carpenter 1994). The tank headspace temperature was determined to be $25.7^{\circ} \mathrm{C}$. Air from the tank BY-108 headspace was withdrawn via a $7.9 \mathrm{~m}$-long heated sampling probe mounted in riser 1 , and transferred via heated tubing to the VSS sampling manifold. All heated zones of the VSS were maintained at approximately $50^{\circ} \mathrm{C}$.

Sampling media were prepared and analyzed by WHC, Oak Ridge National Laboratories (ORNL), and Pacific Northwest Laboratories (PNL). The 40 tank air samples and 2 ambient air control samples collected are listed in Table $2-1$ by analytical laboratory. Table $2-1$ also lists the 14 trip blanks and 2 field blanks that accompanied the samples.

A general description of vapor sampling and sample analysis methods is given by Huckaby et al. (1995). The sampling equipment, sample collection sequence, sorbent trap sample air flow rates and flow times, chain of custody information, and a discussion of the sampling event itself are given in WHC (1995b). 


\subsection{INORGANIC GASES AND VAPORS}

Analytical results of sorbent trap and SUMMA ${ }^{\mathrm{TM}, 1}$ canister tank air samples for selected inorganic gases and vapors are given in Table 3-1 in parts per million by volume (ppmv) in dry air. The concentration of water vapor given in Table 3-1 has been adjusted to tank conditions as given in Section 3.3. Inorganic analyte sorbent traps and SUMMA ${ }^{\mathrm{TM}}$ canisters were prepared and analyzed by PNL at PNL quality assurance impact level 2. McVeety et al. (1995b) describe sample preparation and analyses.

Analyses of inorganic vapor sorbent traps were completed within 20 days of sample collection, but analyses of SUMMA ${ }^{\mathrm{TM}}$ canisters for inorganic compounds were not completed until 79 days after sample collection. Thus the 60-day holding time requirement of the WHC quality assurance project plan (Keller 1994) was satisfied for sorbent trap analyses, but not for SUMMA ${ }^{T M}$ sample inorganic analyses. It should be noted that these inorganic compounds (i.e., the permanent gases) would be expected to be very stable in SUMMA ${ }^{\text {TM }}$ canisters, and the results may not have been affected even though the 60-day holding time requirement was exceeded. The specified 60-day holding time limit was administratively chosen, because no holding time study has been performed to determine the stability of the inorganic compounds in SUMMA ${ }^{\text {TM }}$ canisters in the chemical matrix of tank air samples.

\subsection{Ammonia, Hydrogen, and Nitrous Oxide}

Ammonia concentration in the headspace of tank BY-108 reported to be $1040 \mathrm{ppmv}$, is the highest measured in any passively ventilated tank. Ammonia is thought to be a product of chemical and radiolytic waste degradation processes. It has been observed in virtually all other waste tanks that have been sampled, at concentrations ranging from about 3 ppmv in tank C-108 (Lucke et al. 1995), to 988 ppmv in tank U-106 (Klinger et al. 1995). Given the LFL of ammonia in air is about $15 \%$ by volume (vol\%), the measured $1040 \mathrm{ppmv}$ corresponds to less than $0.7 \%$ of the LFL, and does not contribute appreciably to the flammability of the headspace.

The hydrogen concentration in tank BY-108 was determined to be 399 ppmv. In general, hydrogen is of conncern as a fuel. The measured 399 ppmv of hydrogen in tank BY-108, however, represents only about $1 \%$ of the LFL for hydrogen in air, and is not a flammability concern at this level.

Nitrous oxide was measured to be an average 641 ppmv in the 3 SUMMA ${ }^{\mathrm{TM}}$ canister samples. This is higher than is typical of other passively ventilated tanks, but higher values have been reported. Under proper conditions, nitrous oxide can serve as an oxidizer to support combustion. However, Cashdollar et al. (1992) found that nitrous oxide had no significant effect on the flammability of hydrogen and air mixtures for hydrogen concentrations less than $20 \mathrm{vol} \%$, and that "small amounts of nitrous oxide (relative to air) do not appear to have much effect on the flammability". Their results suggest the measured nitrous oxide concentration is much too low to have a significant effect on the flammability of the tank BY-108 headspace.

\subsection{Carbon Dioxide and Carbon Monoxide}

The average measured headspace carbon dioxide concentration, $224 \mathrm{ppmv}$, is much lower than the normal ambient air concentration of about 350 to $400 \mathrm{ppmv}$. Carbon dioxide introduced by air exchange

1 SUMMA is a trademark of Molectrics, Inc., Cleveland, Ohio. 


\section{WHC-SD-WM-ER-422 REV. 2}

with the atmosphere is readily absorbed by caustic supernatant and interstitial liquids of the waste tanks, and converted to carbonate in soiution., It is reasonable to expect the level of carbon dioxide in a tank headspace will therefore depend on the tank's breathing rate, and the $\mathrm{pH}$ and surface area of aqueous waste (i.e., supernate, interstitial liquid; and condensate) in the tank. The 224 ppmv carbon dioxide concentration measured in tank BY-108 is within the normal range for the passively ventilated tank headspaces.

Carbon monoxide in the tank BY -108 headspace, measured to be $<76$ ppmv, is not well characterized. The method quantitation limit, 76 ppmv, is above the highest waste tank carbon monoxide concentration measured to date ([26.7 ppmv] in tank C-1032 Huckaby and Story 1994). Elevated carbon monoxide concentrations are thought to be due to the decomposition of organic waste in the tanks.

\subsection{Nitric Oxide, Nitrogen Dioxide, Water and Tritium}

Nitric oxide and nitrogen dioxide concentrations in the tank BY-108 headspace were determined to be $s$ 0.03 ppmv and $\leq 0.02$ ppmv, respectively. These are both acid gases that would have very low equilibrium concentrations above the high pH waste in tank BY-108. Nitric oxide is commonly found at trace concentrations, presumably due to its formation from oxygen and nitrogen in the radiation field of the headspace. These constituents could potentially serve as oxidizers to support combustion, but at the measured concentrations would have a negligible effect on the flammability of the tank BY-108 headspace.

The water vapor concentration was measured by gravimetric analysis of 5 sorbent trap systems by PNL (McVeety et al. 1995b). The water vapor concentration of tank BY-108 was determined to be about 13.4 $\mathrm{mg} / \mathrm{L}$, at the tank headspace temperature of $25.7^{\circ} \mathrm{C}$ and pressure of $984 \mathrm{mbar}(737.7$ torr), (WHC 1995b). This corresponds to a water vapor partial pressure of $18.5 \mathrm{mbar}\left(13.9\right.$ torr), to a dew point of $16.3^{\circ} \mathrm{C}$, and to a relative humidity of $56 \%$. It was noted that less mass (water) had been trapped on each successive sample, yet no explanation has been offered for this observation. The relative standard deviation is also higher than typical for this measurement.

Tritium was tested for using silica gel sorbent traps. It is assumed that tritium ions produced by the waste combine with hydroxide ions to form tritium-substituted water. Evaporation of the tritium-substituted water would then result in airborne radioactive contamination. Silica gel sorbent traps adsorb virtually all (normal and tritium-substituted) water vapor from the sampled tank air, and are analyzed at the WHC 222-S laboratory. Analysis of the silica gel indicated the total activity of the sample to be below the method detection limit of 50 pCi/L (WHC 1995b).

\subsection{Discussion of Inorganic Gases and Vapors}

Aside from water vapor, the most abundant waste constituents in the tank BY-108 headspace are ammonia, hydrogen, and nitrous oxide. These have been detected in most tank headspaces sampled to date, and usually are the dominate waste species. However, tank BY-108 headspace contains the highest ammonia concentration(1040 ppmv) measured in any passively ventilated tank headspace, and the hydrogen and nitrous oxide concentrations are both relatively high.

\footnotetext{
2 The carbon monoxide measurement in tank C-103 was made by Oregon Graduate Institute of Science and Technology, and placed in brackets to emphasize it should be considered secondary data.
} 
The relative standard deviations of the inorganic gas and vapor results given in the last column in Table 31 are reasonable for the methods used at the measured concentrations. Relative standard deviations range from $8 \%$ for ammonia to $38 \%$ for carbon dioxide. The precision of reported inorganic gas and vapor measurements has generally been better than this for other tanks. The higher than typical relative standard deviations of the tank BY-108 measurements suggest minor problems with sample air transfer may have occurred, and/or analytical problems. The high ammonia and organic vapor concentrations in tank BY-108 may be partially responsible for the observed precision.

As discussed briefly in Section 1.4, it is possible that gases and vapors generated by the waste in tanks BY-107 and BY-109 could be transferred to tank BY-108 via the cascade lines. If significant exchange of selected inorganic gases and vapors were taking place between adjacent tanks, either their headspace compositions would be very similar (if the exchange is mutual), or all constituents detected in one tank would be at or equal or higher concentrations in the other tank (if air tends to flow consistently from one to the other). Consideration of data in Table 3-2 indicates that the headspace compositions of tanks BY-107 and BY-108 are quite similar, but with generally lower concentrations being found in tank BY-107. The data are consistent with the premise that the cascade line between them plays a significant role in their ventilation, but does not prove this occurs. Results for tank BY-109 presented in Table 3-2 are from the September 1994 ISS event, and represent the only available data for that tank. The contrasting ammonia, hydrogen, and nitrous oxide concentrations in tanks BY-108 and BY-109 suggest tank BY-109 is not affecting the headspace of tank BY-108 significantly. 


\subsection{ORGANIC VAPORS}

Organic vapors in the tank BY-108 headspace were sampled using SUMMA ${ }^{\mathrm{TM}}$ canisters, which were analyzed by PNL, and triple sorbent traps (TSTS), which were analyzed by ORNL. Both laboratories used a gas chromatograph (GC) equipped with a mass spectrometer (MS) to separate, identify, and quantitate the analytes. Descriptions of sample device cleaning, sample preparations, and analyses are given by Jenkins et al. (1995) and McVeety et al. (1995b). A quantitative measurement of the total organic vapor concentration by the U.S. Environmental Protection Agency (EPA) task order 12 (TO-12) method (EPA 1988) was also performed by Oregon Graduate Institute of Science and Technology (OGIST) on samples collected in March 1994 by the ISS method (Rasmussen 1994a).

SUMMA ${ }^{\mathrm{TM}}$ sample results should be considered to be the primary organic vapor data for tank BY-108. These results were produced at PNL quality assurance impact level 2. However, PNL analyses of organic vapors in SUMMA ${ }^{\mathrm{TM}}$ canisters were not completed until 87 days after sample collection, which exceeded the administratively chosen 60-day holding time allowed by the WHC quality assurance project plan (Keller 1994). No holding time study has been performed to determine the stability of the organic analytes in SUMMA ${ }^{\text {TM }}$ canisters in the chemical matrix of tank air samples.

ORNL analyses of TST samples from this and other waste tanks generally agree with, support, and augment the SUMMA ${ }^{\text {TM }}$ sample results. However, because certain WHC quality assurance requirements were not satisfied by ORNL, the quality assurance assessment of ORNL by Hendrickson (1995) should be reviewed before results unique to the TST samples are used for decision making.

All TSTs prepared by ORNL had 3 surrogate compounds added to evaluate sample matrix effects, potential handling, storage, and shipment problems, and analytical instrumentation performance (Jenkins et al. 1995a). ORNL evaluated the surrogate recoveries using a statistical approach similar to that prescribed by SW 846 Method 8260 A Volatile Organic Compounds by Gas Chromatography/Mass Spectrometry (GC/MS) Capillary Column Technique (EPA 1992). Using this approach, ORNL reported that all surrogates had standard deviation values outside the $95 \%$ confidence interval for variance, suggesting that a bias may have been introduced in the measurement of analyte quantities (Jenkins 1995a).

\subsection{Positively Identified Organic Analytes}

Positive identification of organic analytes using the methods employed by PNL and ORNL involves matching the $\mathrm{GC}$ retention times and MS data from a sample with that obtained by analysis of standards. The concentration of an analyte in the sample is said to be quantitatively measured if the response of the GC/MS has been established at several known concentrations of that analyte (i.e., the GC/MS has been calibrated for that analyte), and the MS response to the anaiyte in the sample is between the lowest and highest responses to the known concentrations (i.e., the analyte is within the calibration range).

ORNL and PNL were assigned different lists of organic compounds, or target analytes, to positively identify and measure quantitatively. The ORNL target analyte list was derived from a review of the tank C103 headspace constituents by a panel of toxicology experts (Mahlum et al. 1994). The PNL target analyte list included 40 compounds in the Environmental Protection Agency (EPA) task order 14 (TO-14) method, which are primarily halocarbons and common industrial solvents (EPA 1988), plus 14 analytes selected mainly from the toxicology panel's review of vapor data on tank C-103. 


\section{WHC-SD-WM-ER-422 REV. 2}

Listed in Table 4-1 are the organic compounds positively identified and quantitated in SUMMA ${ }^{\mathrm{TM}}$ canister samples by PNL. PNL performed analyses according to the EPA task order 14 (TO-14) methodology, but expanded the number of target analytes from 40 to 54 to include waste tank analytes of particular interest (EPA 1988, McVeety et al. 1995b). Of the original 40 TO-14 analytes, 32 were determined to be below the 0.002 ppmv quantitation limit of the analyses, and 3 of the 15 additional target analytes (ethanenitrile, propanenitrile, and $n$-butanenitrile) were below the 0.005 ppmv method quantitation limit. Averages reported are from analyses of 3 SUMMA ${ }^{\text {TM }}$ canister samples.

ORNL positively identified 23 of 27 target analytes selected by WHC. Four target analytes $(1,1-$ dichloroethene, $n$-heptanenitrile, tributyl phosphate and dibutyl butylphosphonate) were below their detection limits. Despite calibration of the instrument over about a 20 -fold concentration range, the measured values for 9 of the 23 positively identified compounds were outside of the calibration range in at least 1 of the TST samples, and were not quantitated. The positively identified compounds, and their average concentrations from the analysis of 3 TSTs, are given in Tables 4-2, 4-3, and 4-4. Table 4-2 lists 12 quantitated compounds, Table 4-3 lists 8 compounds which were not quantitated in all 3 TST samples, and Table 4-4 lists 3 compounds for which the ORNL practical holding times were exceeded. Tables 4-2, 4-3, and 4-4 are mutually exclusive, so no compound appears in more than 1 table. Data in Tables 4-3 and $4-4$ may not be accurate to within $\pm 30 \%$ as specified by Burnum (1995).

Based on a practical holding time study performed by ORNL the reported concentrations of butanal, 1butanol, and 2-pentanone may have been affected by the 39-day period between sample collection and analysis (Jenkins 1995b). The concentration of these 3 analytes are reported in Table 4-4. The practical holding time is defined as the holding time for which there is a $15 \%$ risk that the concentration of an analyte in the sample will be below its initial concentration. Jenkins et al. (1995b) describe the ORNL practical holding time study, and report practical holding times for butanal, 1-butanol, and 2-pentanone to be 1,17 , and 34 days respectively. It should be noted that the contractual holding time for the TST samples was 60 days.

The 11 target analytes common to both the ORNL and PNL analyses are listed with their measured concentrations in TST and SUMMA ${ }^{\mathrm{TM}}$ canister samples in Table 4-5. Comparison of the results from the 2 laboratories indicates the following:

1) An acceptable agreement for propanone and certain nonpolar analytes (i.e., n-hexane, nheptane, toluene, and n-decane);

2) TST analyses indicate dichloromethane to be present at an average concentration of $1.2 \mathrm{ppmv}$, while none was detected in SUMMA ${ }^{\text {TM }}$ canister samples;

3) TST analyses indicate ethanenitrile to be $0.94 \mathrm{ppmv}$, and n-butanenitrile to be $0.31 \mathrm{ppmv}$, while SUMMA ${ }^{\mathrm{TM}}$ analyses indicate each of these to be below their quantitation limit of $0.005 \mathrm{ppmv}$; and

4) the 2 methods disagree on the concentration of benzene by roughiy a factor of 7 .

The TST dichloromethane results are questionable. Individual TST sample results are relatively inconsistent; the individual results are $0.30,2.3$, and $1.0 \mathrm{ppmv}$, which average to $1.2 \mathrm{ppmv}$, have a standard deviation of $1.0 \mathrm{ppmv}$, and a relative standard deviation of $83 \%$.

Though the discrepancy between the TST and SUMMA ${ }^{\mathrm{TM}}$ sample nitrile results is currently not understood, the reported concentrations are not above action limits. 
The most abundant analytes in Tables 4-1 through 4-4, neglecting the TST dichloromethane result, are 1butanol, propanone, 1-propanol, $n$-hexane and tetrahydrofuran, each of which was measured to be above $1 \mathrm{ppmv}$. At the reported concentrations, the positively identified organic compounds do not individually or cumulatively represent a flammability hazard.

\subsection{Tentatively Identified Organic Analytes}

- In addition to the target analytes, the ORNL and PNL analytical procedures allow the tentative identification of other organic compounds. Tentative identification of analytes was performed by comparing the MS molecular fragmentation patterns with a library of known MS fragmentation patterns. This method allows an organic analyte to be identified (with reasonable certainty) as an alkane, a ketone, an aldehyde, etc., and may also determine its molecular weight. The method usually does not, however, allow the unambiguous identification of structural isomers, and this ambiguity increases with analyte molecular weight. Using this method, many analytes can be tentatively identified with reasonable confidence without having to inject each into the GC/MS to determine their GC retention times or specific MS patterns.

By the nature of the sampling devices, virtually all organic vapors present in the tank headspace are collected by both TST and SUMMA ${ }^{\text {TM }}$ samples. Analyses of the samples are designed to recover, separate, and identify the organic vapors in the samples. TSTS are not good for collecting highly volatile compounds (i.e., molecules more volatile than propane), but are quite good for most others. In contrast, the recovery of very low volatility compounds (e.g., molecules with more than about 15 carbon atoms) and some polar compounds with moderate volatility (e.g., butanal) from SUMMA ${ }^{\text {TM }}$ samples has been problematic.

The organic compounds tentatively identified in SUMMA ${ }^{\mathrm{TM}}$ canister samples by PNL are listed, with their estimated concentrations, in Table 4-6. Compounds are listed in Table $4-6$ in the order by which they eluted chromatographically, and only non-zero results are included in the reported averages. The list of tentatively identified compounds detected in TST samples, and their estimated concentrations, is given in Table 4-7. Compounds are listed in Table 4-7 according to the order by which the eluted chromatographically. The averages reported by ORNL in Table 4-7 are all 3-sample averages, and if an analyte was not detected in a sample, its concentration in that sample was considered to be zero for averaging purposes. Estimated concentrations are in $\mathrm{mg} / \mathrm{m}^{3}$, based on dry air at $0^{\circ} \mathrm{C}$ and 1.01 bar.

Because the list of tentatively identified organic compounds in TST samples is especially long ( $>200$ compounds) and difficult to analyze, the list has been sorted alphanumerically by compound name in Table 4-8, and also in order of decreasing estimated concentrations Table 4-9. Numbers in the first columns of Tables 4-8 and 4-9 (Cmpd \#) identify the location of the compound in Table 4-7.

The ORNL and PNL methods used to tentatively identify and estimate concentrations are described by Jenkins et al. (1995a) and McVeety et al. (1995b), respectively, and should be reviewed before this data are used for decision making. Results in Tables 4-6 through 4-9 are presented in terms of observed peaks, and are not adjusted for the occurrence of split chromatographic peaks (e.g., Cmpd \# 96 and 99 in Table 4-7). In these instances, the estimated concentration of a compound appearing as a doublet or triplet is simply the sum of the individual peak estimates.

Concentrations given in Tables 4-6 through 4-9 should be considered rough estimates. The proper quantitation of all observed analytes is outside the scope and budget of these analyses, and the 
estimation of concentrations involves several important assumptions. The validity of each assumption depends on the analyte, and such factors as the specific configuration of the analytical instrumentation.

\subsection{Total Nonmethane Organic Carbon}

OCIST measured the TNMOC concentration in 3 SUMMA ${ }^{\text {TM }}$ canister samples collected on March 28 , 1994 using the EPA TO-12 method (Rasmussen 1994a). Because OGIST did not have a WHC-approved quality assurance project plan in place when the samples were analyzed, this data should be considered secondary, and has been placed in brackets. The sample mean was $\left[594 \mathrm{mg} / \mathrm{m}^{3}\right]$, with a standard deviation of [14 $\left.\mathrm{mg} / \mathrm{m}^{3}\right]$. This value is very high compared to other waste tanks sampled to date. Only tank C-103, estimated to have $\left[3,000\right.$ to $\left.5,000 \mathrm{mg} / \mathrm{m}^{3}\right]$ of TNMOC (Rasmussen and Einfeld 1994), is known to have a higher TNMOC concentration. For comparison, the TNMOC concentration in clean ambient air may range from 0.03 to $0.1 \mathrm{mg} / \mathrm{m}^{3}$, in polluted city air it may be 0.3 to $0.4 \mathrm{mg} / \mathrm{m}^{3}$.

\subsection{Discussion of Organic Analytes}

Some of the compounds listed in Tables 4-1 through 4-9 were introduced to the tank with process waste streams, and are detected in the headspace because the original inventory has not been completely evaporated or degraded. Examples of these are the semivolatile normal paraffinic hydrocarbons (NPHs), (i.e., n-dodecane, n-tridecane, n-tetradecane, n-pentadecane) and methyl-substituted decahydronaphthalenes that were used as diluents for tributyl phosphate.

Most of the compounds in Tables 4-1 through 4-9 are believed to be chemical reaction and radiolytic reaction products of the semivolatile or nonvolatile organic waste stored in the tank. For example, 1butanol is known to be formed by the hydrolysis of tributyl phosphate, and it is thought that the alcohols, aldehydes, ketones, nitriles, alkenes, and short chain alkanes are all degradation products of NPHs.

Neither TST nor SUMMA ${ }^{\text {TM }}$ methods detected tributyl phosphate as a headspace constituent. The relatively high concentration of 1-butanol, however, is a strong indication that tributyl phosphate does exist in tank BY-108. That tributyl phosphate was not observed in the TST samples may be due to the facts that tributyl phosphate has a very low vapor pressure, and it has a tendency to be adsorbed by the high efficiency particulate air filters used during sampling to protect the samples from radiological particulate contamination.

In the semivolatile region of Tables 4-6 and 4-7, there are many branched alkanes. The abundance of these, as well as the decahydronaphthalenes, was also noted in tank BY-107, to which tank BY-108 is attached.

It is interesting,to note that while there are many ketones identified (particularly 2-alkanones, of which the homologous series from propanone to 2-nonanone, and several others exist), there are only 3 aldehydes identified. In other NPH-rich tanks (notably sludge tanks in 241-C farm, e.g., C-108, C-109, C-111 and C112) the aldehydes and ketones are found in comparable numbers. This may be indicative of the oxidative properties of the waste, as the oxidation of an aldehyde to an acid is chemically easier than the oxidation of ketones.

Similariy, tank BY-108 has fewer nitriles than other NPH-rich tanks. Camaioni et al. (1994) point out that the hydrolysis of aldoximes produces aidehydes, while the dehydration of aldoximes produces nitriles. 


\section{WHC-SD-WM-ER-422 REV. 2}

The observation that nitriles and aldehydes are found together in some tanks, and almost not at all in other NPH-rich tanks, appears to support the proposed aldoxime hydrolysis mechanism.

Though there is no toxicological or flammability hazard associated with the 0.13 ppmv of trichlorofluoromethane measured in tank BY-108 SUMMA ${ }^{\mathrm{TM}}$ samples, its presence has been noted in many of the tanks sampled to date. The origin of trichlorofluoromethane in the waste tanks has not been established, however, it may be present from its use in urethane foam that were applied to concrete tank pits as a sealant.

The concentrations of organic vapors in tank BY-108 are generally very high compared to other passively ventilated tanks that have been sampled. It has the second highest known TNMOC concentration of any tank. In character the organic vapors in tank BY-108 are very similar to tank BY-107, to which it is connected via a cascade line. Because there are clearly a higher concentrations of organic vapors in tank BY-108 than in either tank BY-107 or tank BY-109 (Table 3-2), the origin of the organic vapors in tank BY108 appears to be the waste stored in that tank. 


\subsection{SUMMARY}

The tank BY-108 headspace was sampled in March 1994 and October 1994 for gases and vapors to address flammability and industrial hygiene concerns. Results unique to the March 1994 event and essentially all results from the October 1994 event have been reported. It was determined that no headspace constituents exceeded the flammability notification limits, but that ammonia, measured to be $1080 \mathrm{ppmv}$, exceeded the $150 \mathrm{ppmv}$ industrial hygiene notification limits specified in the current Vapor Sampling and Analysis Plan (Homi 1995). 
WHC-SD-WM-ER-422 REV. 2

\subsection{REFERENCES}

29 CFR 1910.120, 1993, "Hazardous Waste Operations and Emergency Response", Code of Federal Regulations.

Burnum, S. T., 1995, Qualification of Reported WHC Vapor Program Data, (letter 95-CHD-065 to president, Westinghouse Hanford Company, August 18), Department of Energy, Richland Operations Office, Richland, Washington.

Camaioni, D. M., W. D. Samuals, B. D. Lenihan, S. A. Clauss, K. L. Wahl, and J. A. Campbell, 1994, Waste Aging Studies, PNL-10161, UC-2030, Pacific Northwest Laboratory, Richland, Washington.

Carpenter, B. C., 1994, Tank 241-BY-108 Tank Characterization Plan, WHC-SD-WM-TP-275 Rev OA, Westinghouse Hanford Company, Richland, Washington.

Cashdollar, K. L..,M. Hertaberg, I. A. Zlochower, C. E. Lucci, G. M. Green, and R. A. Thomas, 1992, Laboratory Flammability Studies of Mixtures of Hydrogen, Nitrous Oxide, and Air, WHC-SD-WMES-219 Rev. 0, Westinghouse Hanford Company, Richland, Washington.

Dougherty, L. F., 1995, Single Shell Tank Interim Operational Safety Requirements, WHC-SD-WM-OSR005 Rev. 0, Westinghouse Hanford Company, Richland, Washington.

EPA 1988, Compendium of Methods for the Determination of Toxic Organic Compounds in Ambient Air, PB90-127374, U.S. Environmental Protection Agency, Washington, D.C.

EPA 1992, Test Methods for Evaluating Solid Waste, SW-846 Rev. 1, U.S. Environmental Protection Agency, Washington, D.C.

Farley, W. G., 1991, Safety Assessment for Gas Sampling All Ferrocyanide Tanks, WHC-SD-WM-SAD009 Rev. 2, Westinghouse Hanford Company, Richland, Washington.

Hendrickson, R. W., 1995, Tank Vapor Characterization Oak Ridge National Laboratories Quality Assurance Assessment, TWRSQA-95-0012, Westinghouse Hanford Company, Richland, Washington.

Homi, C. S., 1995, Vapor Sampling and Analysis Plan, WHG-SD-WM-TP-335 Rev. OG, Westinghouse Hanford Company, Richland, Washington.

Huckaby, J. L., 1994a, Vapor Sampling System (VSS) and In Situ Sampling (ISS) Method Comparison, . WHC-SD-WM-RPT-101 Rev. 0, Westinghouse Hanford Company, Richland, Washington.

Huckaby, J. L., 1994b, Tank 241-C-103 Headspace Flammability, WHC-EP-0734 Rev. 1, Westinghouse Hanford Company, Richland, Washington.

Huckaby, J. L., H. Babad, and D. R. Bratzel, 1995,Headspace Gas and Vapor Characterization Summary for the 43 Vapor Program Suspect Tanks, WHC-SD-WM-ER-514, Rev. 0, Westinghouse Hanford Company, Richland, Washington. 
Huckaby, J. L., and D. R. Bratzel, 1995, Tank 241-BY-107 Headspace Gas and vapor Characterization Results for Samples Collected in March 1994 and October 1994, WHC-SD-WM-ER-421 Rev. 1, Westinghouse Hanford Company, Richland, Washington.

Huckaby, J. L., and M. S. Story, 1994, Vapor Characterization of Tank 241-C-103, WHC-EP-0780 Rev. 0, Westinghouse Hanford Company, Richland, Washington.

Jenkins, R. A., 1995a, Untitled, (Letter 090195A to D. Bratzel, September 1), Oak Ridge National Laboratory, Oak Ridge, Tennessee

Jenkins, R. A., 1995b, Untitled, (Letter 091495A to D. Bratzel, September 14), Oak Ridge National Laboratory, Oak Ridge, Tennessee.

Jenkins, R. A, A. B. Dindal, C. E. Higgins, C. Y. Ma, M. A. Palausky, and J. T. Skeen, 1994a, Analysis of Tank 241-BY-109 Headspace Components, Oak Ridge National Laboratory, Oak Ridge, Tennessee.

Jenkins, R. A, A. B. Dindal, C. E. Higgins, C. Y. Ma, M. A. Palausky, J. T. Skeen, and C. K. Bayne, 1995a, Analysis of Tank 241-BY-108 Headspace Components, ORNL-CASD-FR-241BY108.95 Rev. 0, Oak Ridge National Laboratory, Oak Ridge, Tennessee.

Jenkins, R. A, A. B. Dindal, C. Y. Ma, M. A. Palausky, J. T. Skeen, and C. K. Bayne, 1995b, Analysis of Tank 241-TY-104 Headspace Components, ORNL-CASD-FR-241TY104.95 Rev. 1, Oak Ridge National Laboratory, Oak Ridge, Tennessee.

Keller, K.K., 1994, Quality Assurance Project Plan for Tank Vapor Characterization, WHC-SD-WM-QAPP013 Rev. 2, Westinghouse Hanford Company, Richland, Washington.

Klinger, G. S., T. W. Clauss, M. W. Ligotke, K. H. Pool, B. D. MoVeety, K. B. Olsen, O. P. Bredt, J. S. Fruchter, and S. C. Coheen, 1995, Vapor Space Characterization of Waste Tank 241-U-106: Results from 'Samples Collected on 3/7/95, PNL-10593 UC-606, Pacific Northwest Laboratory, Richland, Washington.

Lucke, R. B., M. W. Ligotke, K. H. Pool, T. W. Clauss, A. K. Sharma, B. D. McVeety, M. McCulloch, J. S. Fruchter, and S. C. Goheen, 1995, Vapor Space Characterization of Waste Tank 241-C-108: Results from Samples Collected Through the Vapor Sampling System on 8/5/94, PNL-10351 UC606, Pacific Northwest Laboratory, Richland, Washington.

Mahlum, D. D., J. Y. Young, and R. E. Weller, 1994, Toxicologic Evaluation of Analytes from Tank 231-C103, PNL-10189, Pacific Northwest Laboratory, Richland, Washington.

McVeety, B. D., R. B. Lucke, T. W. Clauss, J. S. Fruchter, and S. C. Goheen, 1995a, Vapor Space Characterization of Waste Tank 241-BY-108: Results from In Situ Sample Collected on 3/24/94, PNL-10288 UC-606, Pacific Northwest Laboratory, Richland, Washington.

McVeety, B. D., T. W. Clauss, M. W. Ligotke, K. H. Pool, R. B. Lucke, G. S. Klinger, J. S. Young, M. McCulloch, J. S. Fruchter, and S. C. Goheen, 1995b, Vapor Space Characterization of Waste Tank 241-BY-108: Results from Samples Collected on 10/27/94, PNL-10495 UC-606, Pacific Northwest Laboratory, Richland, Washington. 


\section{WHC-SD-WM-ER-422 REV, 2}

Meacham, J. E., H. Babad, R. J. Cash, G. T. Dukelow, S. J. Eberlein, D. W. Hamilton, G. D. Johnson, J. W. Osborne, M. A. Payne, D. J. Sherwood, D. A. Turner, and J. L. Huckaby, 1995, Approach for Tank Safety Characterization of Hanford Site Waste, WHC-EP-0843 Rev. 0, UC-2070, Westinghouse Hanford Company, Richland, Washington.

NFPA 1992, Standard on Explosion Prevention Systems, NFPA 69, National Fire Protection Association, Quincy, Massachusetts.

Osborne, J. W., and J. L. Huckaby, 1994, Program Plan for the Resolution of Tank Vapor issues, WHCEP-0562 Rev. 1, Westinghouse Hanford.Company, Richland, Washington.

Osborne, J. W., J. L. Huckaby, T. P. Rudolph, E. R. Hewitt, D. D. Mahlum, J. Y. Young, C. M. Anderson, 1994, Data Quality Objectives for Generic In-Tank Health and Safety Issue Resolution, WHC-SDWM-DQO-002, Westinghouse Hanford Company, Richland, Washington.

Pingel, L. A., 1994a, Draft Results from the Vapor Sampling of Waste Tank BY-108, (Internal memorandum 12920-SAS94-081 to G. T. Dukelow, J. L. Huckaby, E. H. Neilsen, and W. H. Ulbricht, April 13), Westinghouse Hanford Company, Richland, Washington.

Pingel, L. A., 1994b, Data Report from the In-Situ Vapor Sampling of Waste Tank BY-109, (Internal memorandum 8H130-SAS94-114 to J. L. Huckaby, October 4), Westinghouse Hanford Company, Richland, Washington.

Pool, K. H., T. W. Clauss, M. W. Ligotke, R. B. Lucke, B. D. McVeety, J. S. Young, M. McCulloch, J. S. Fruchter, and S. C. Goheen, 1995, Vapor Space Characterization of Waste Tank 241-BY-109 (In Situ): Results from Samples Collected on 9/22/94, PNL-10389 UC-606, Pacific Northwest Laboratory, Richland, Washington.

Rasmussen, R. A., 1994a, Air Samples Collected at Waste Tanks BY-107 and BY-108 on March 25 and 28, 1994 by Westinghouse Hanford in 6-L SS SUMMA® Canisters, Oregon Graduate Institute of Science and Technology, Beaverton, Oregon.

Rasmussen, R. A., 1994b, Air Samples Collected at Waste Tank 241-BY-109 on September 22, 1994 by Westinghouse Hanford in 6-L SS SUMMA® Canisters, Oregon Graduate Institute of Science and Technology, Beaverton, Oregon.

Rasmussen, R. A., and W. Einfeld, '1994, Hanford Tank 103-C Analyses and Method Validation Development Phase, SAND94-1807, Sandia National Laboratories, Albuquerque, New Mexico.

WHC 1995a, Operating Specifications for Watchlist Tanks, OSD-T-151-00030, Rev. B-9, Westinghouse Hanford Company, Richland, Washington.

WHC 1995b, Vapor and Gas Sampling of Single-Shell Tank 241-BY-108 Using the Vapor Sampling System, WHC-SD-WM-RPT-121, Westinghouse Hanford Company, Richland, Washington. 


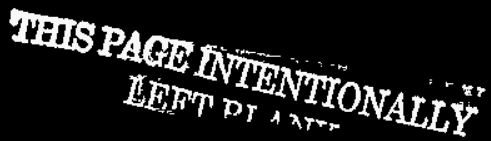




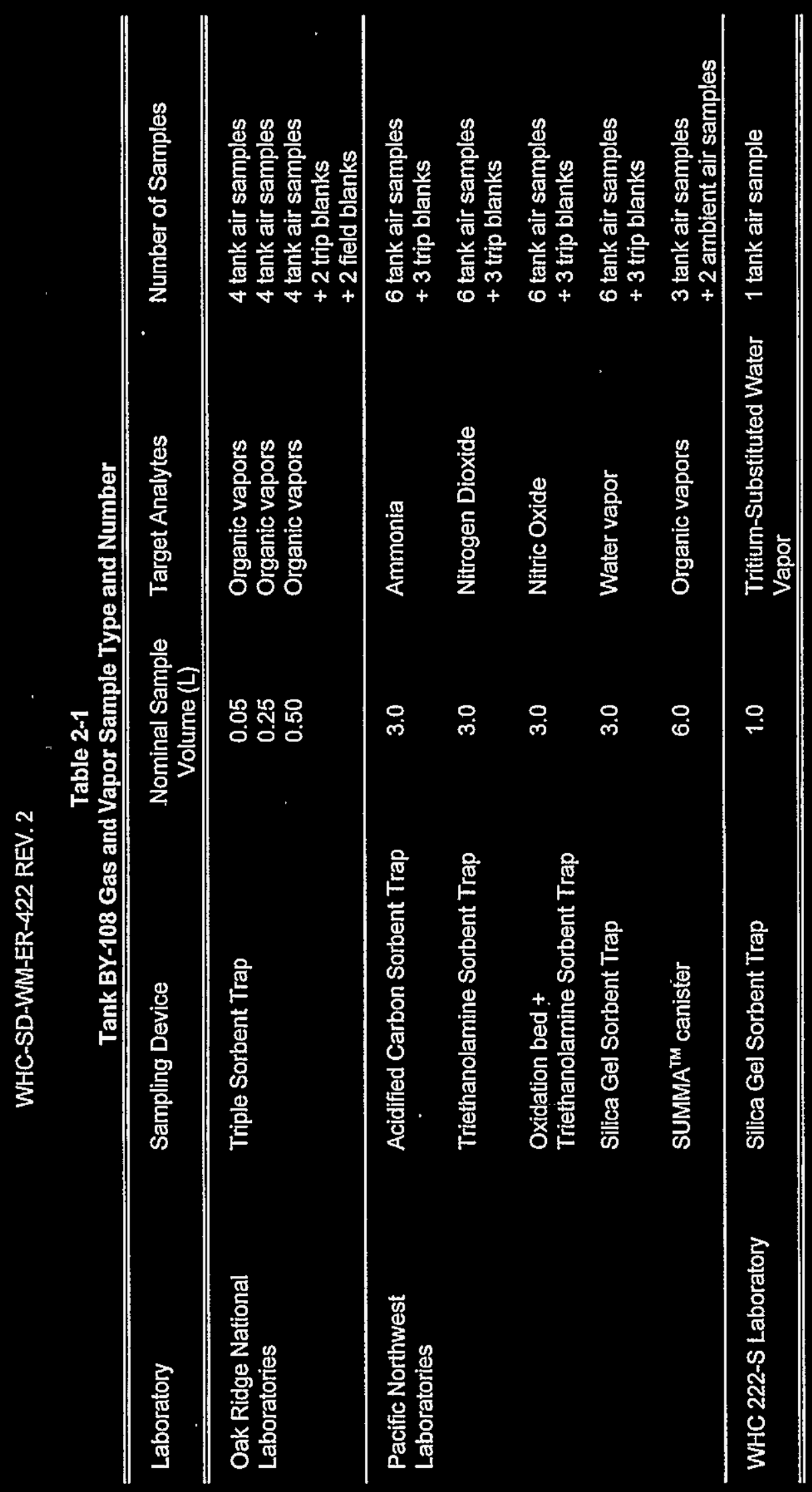




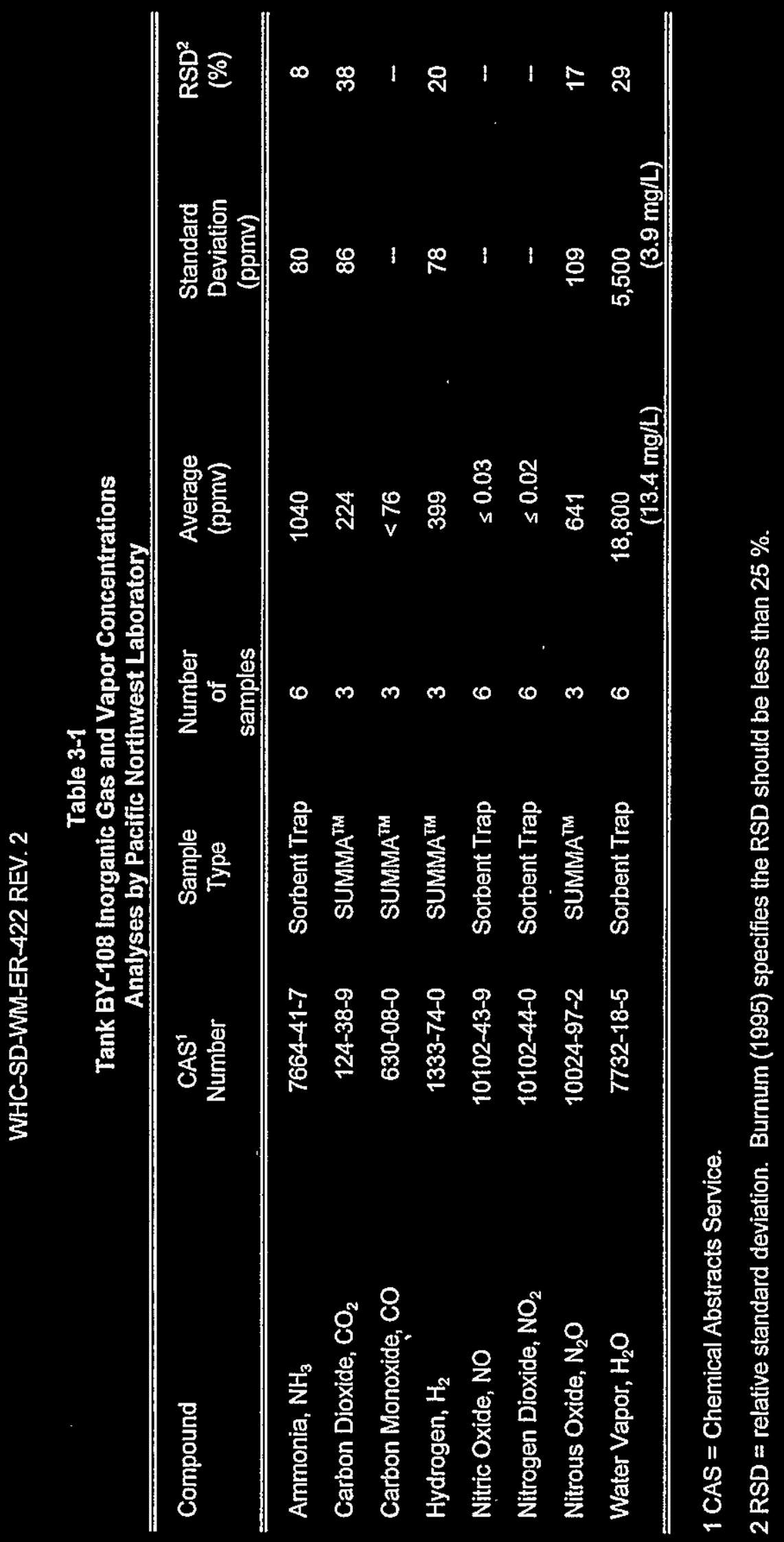


Table 3-2

Comparison of Tank BY-107, BY-108, and BY-109 Headspace Constituents ${ }^{1}$

\begin{tabular}{|c|c|c|c|}
\hline Tank: & BY $-107^{2}$ & BY-108 & $B Y-109^{3}$ \\
\hline Date sampled, (mo/day/yr) & $10 / 26 / 94$ & $10 / 27 / 94$ & $9 / 22 / 94$ \\
\hline Headspace temperature, $\left({ }^{\circ} \mathrm{C}\right)$ & 33.1 & 25.7 & 26.5 \\
\hline Ammonia, (ppmv) & 972 & 1040 & 46 \\
\hline Hydrogen, (ppmv) & $267^{\bullet}$ & 399 & {$[56.3]$} \\
\hline Carbon dioxide, (ppmv) & 94 & 224 & [126] \\
\hline Carbon monoxide, (ppmv) & $<20$ & $<76$ & {$[0.41]$} \\
\hline Nitric oxide, (ppmv) & 0.13 & $\leq 0.03$ & $\leq 0.04$ \\
\hline Nitrogen dioxide, (ppmv) & $\leq 0.02$ & $\leq 0.02$ & $\leq 0.03$ \\
\hline Nitrous oxide, (ppmv) & 621 & 641 & {$[10.7]$} \\
\hline Water vapor, $\left(\mathrm{mg} / \mathrm{m}^{3}\right)$ & 13.0 & 13.4 & - \\
\hline Water vapor, (\% relative humidity) & 36 & 56 & - \\
\hline Ethanenitrile (acetonitrile), (ppmv) & $(2.2)$ & 0.94 & 0.083 \\
\hline Propanone (acetone), (ppmv) & (3.9) & $(8.2)$ & $(0.39)$ \\
\hline 1-Butanol, (ppmv) & (7.9) & (58) & $(0.79)$ \\
\hline n-Dodecane, (ppmv) & 0.21 & 0.80 & $(0.17)$ \\
\hline n-Tridecane, (ppmv) & $(0.26)$ & 0.73 & $(0.27)$ \\
\hline Total organic compounds ${ }^{4},\left(\mathrm{mg} / \mathrm{m}^{3}\right)$ & 149.4 & 510 & 20.3 \\
\hline
\end{tabular}

1 Inorganic gas or vapor results are from PNL except where noted for tank BY-109; organic vapor results are from ORNL, with non-quantitative values in parentheses and quantitative values not in parentheses.

2 Data are from Huckaby and Bratzel 1995.

3 Results for BY-109 are from an ISS event, and presented for comparison only. Values in brackets are from OGIST (Rasmussen 1994b), and shouid be considered secondary data. Sample volume measurements used by PNL to calculate the ammonia, nitric oxide, and nitrogen dioxide concentrations (Pool et al. 1995), and by ORNL to calculate the organic vapor concentrations (Jenkins et al. 1994), may not be accurate to within $20 \%$. Pingel (1994b) describes the sampling event.

4 Total organic compound concentration was estimated from TST sample results. 
WHC-SD-WM-ER-422 REV. 2

Table 4-1

Tank BY-108 Quantitatively Measured Organic Compound Average Concentrations -Analyses by Pacific Northwest Laboratory

\begin{tabular}{|c|c|c|c|c|c|}
\hline$\underset{\#}{\text { Cmpd }}$ & Compound & $\begin{array}{c}\text { CAS }^{1} \\
\text { Number }\end{array}$ & $\begin{array}{c}\text { Average } \\
\text { (ppmv) }\end{array}$ & $\begin{array}{c}\text { Standard } \\
\text { Deviation } \\
\text { (ppmv) }\end{array}$ & $\begin{array}{l}\mathrm{RSD}^{3} \\
(\%)\end{array}$ \\
\hline 1 & Trichlorofluoromethane & $75-69-4$ & 0.128 & 0.064 & 5 \\
\hline 2 & Propanone (acetone) & - $67-64-1$ & 4.4 & 0.5 & 11 \\
\hline 3 & 1-Propanol & $71-23-8$ & 6.8 & 0.1 & 2 \\
\hline 4 & 2-Butanone & $78-93-3$ & 0.54 & 0.33 & 60 \\
\hline 5 & n-Hexane & $110-54-3$ & 1.5 & 0.04 & 2 \\
\hline 6 & Benzene & $71-43-2$ & 0.025 & 0.001 & 2 \\
\hline 7 & 4-Methyl-2-pentanone & $108-10-1$ & 0.037 & 0.001 & 2 \\
\hline 8 & Cyclohexane & $110-82-7$ & 0.14 & 0.005 & 3 \\
\hline 9 & n-Heptane & $142-82-5$ & $0.52^{\circ}$ & 0.01 & 2 \\
\hline 10 & Tetrahydrofuran & $109-99-9$ & 1.29 & 0.02 & 2 \\
\hline 11 & Toluene & $108-88-3$ & 0.045 & 0.002 & 3 \\
\hline 12 & Ethylbenzene & $100-41-4$ & 0.185 & 0.0005 & 0.3 \\
\hline 13 & $\begin{array}{l}\text { 1,3-Dimethylbenzene (m-xyiene) }+ \\
\text { 1,4-Dimethylbenzene ( } \mathrm{p} \text {-xylene })^{4}\end{array}$ & $\begin{array}{l}108-38-3 \\
106-42-3\end{array}$ & 0.077 & 0.003 & 4 \\
\hline 14 & o-Xylene & $95-47-6$ & 0.024 & 0.001 & 5 \\
\hline 15 & Cyciohexanone & $108-94-1$ & 0.010 & 0.002 & 16 \\
\hline 16 & n-Decane & $124-18-5$ & 0.090 & 0.002 & 3 \\
\hline 17 & Methane & $74-82-8$ & $<61$ & - & - \\
\hline
\end{tabular}

$1 \mathrm{CAS}=$ Chemical Abstract Service.

2 Average of 3 samples.

3 RSD = relative standard deviation. Burnum (1995) specifies the RSD should be less than $25 \%$.

$4 \mathrm{~m}$-xylene and $\mathrm{p}$-xylene coelute and the reported value represents the sum of their concentrations. 
WHC-SD-WM-ER-422 REV. 2

Table 4.2

Tank BY-108 Quantitatively Measured Organic Compound Average Concentrations -and Oak Ridge National Laboratory ${ }^{1}$

\begin{tabular}{|c|c|c|c|c|c|}
\hline$\underset{\#}{\text { Cmpd }}$ & Compound & $\begin{array}{c}\text { CAS }^{2} \\
\text { Number }\end{array}$ & $\begin{array}{c}\text { Average }^{3} \\
\text { (ppmv) }\end{array}$ & $\begin{array}{c}\text { Standard } \\
\text { Deviation } \\
\text { (ppmv) }\end{array}$ & $\begin{array}{c}\mathrm{RSD}^{4} \\
(\%)\end{array}$ \\
\hline 1 & $\begin{array}{l}\text { Ethanenitrile } \\
\text { (acetonitrile) }\end{array}$ & $75-05-8$ & 0.94 & 0.18 & 19 \\
\hline 2 & Dichloromethane & $75-09-2$ & 1.2 & 1.0 & 85 \\
\hline 3 & Butanenitrile & $109-74-0$ & 0.31 & 0.04 & 12 \\
\hline 4 & n-Heptane & $142-82-5$ & 0.89 & 0.03 & 3 \\
\hline 5 & 2-Hexanone & $591-78-6$ & 0.16 & 0.02 & 15 \\
\hline 6 & n-Octane & $111-65-9$ & 0.33 & 0.08 & 23 \\
\hline 7 & 2-Heptanone & $110-43-0$ & 0.14 & 0.03 & 19 \\
\hline 8 & n-Nonane & $111-84-2$ & 0.19 & 0.03 & 14 \\
\hline 9 & n-Decane & $124-18-5$ & 0.21 & 0.10 & 46 \\
\hline 10 & n-Undecane & $1120-21-4$ & 0.48 & 0.09 & 19 \\
\hline 11 & n-Dodecane & $112-40-3$ & 0.80 & 0.18 & 22 \\
\hline 12 & $\mathrm{n}$-Tridecane & $629-50-5$ & 0.73 & 0.22 & 30 \\
\hline
\end{tabular}

1 Results in this table are quantitative (as defined in Section 4.1).

$2 \mathrm{CAS}=$ Chemical Abstract Service.

3 Average of $3,55 \mathrm{ml}$ TST samples.

4 RSD = relative standard deviation. Burnum (1995) specifies the RSD should be less than $25 \%$. 
WHC-SD-WM-ER-422 REV. 2

\section{Table 4-3}

Tank BY-108 Positively Identified Organic Compound Average Concentrations and Oak Ridge National Laboratory'.

\begin{tabular}{clcccc}
\hline \hline $\begin{array}{c}\text { Cmpd } \\
\#\end{array}$ & Compound & $\begin{array}{c}\text { CAS } \\
\text { Number }\end{array}$ & $\begin{array}{c}\text { Average } \\
\text { (ppmv) }\end{array}$ & $\begin{array}{c}\text { Standard } \\
\text { Deviation } \\
\text { (ppmv) }\end{array}$ & $\begin{array}{c}\mathrm{RSD}^{4} \\
(\%)\end{array}$ \\
\hline \hline 1 & Propanone (acetone) & $67-64-1$ & 8.2 & 0.6 & 7 \\
2 & Propanenitrile & $107-12-0$ & 0.048 & 0.002 & 4 \\
3 & n-Hexane & $110-54-3$ & 2.3 & 0.1 & 3 \\
4 & Benzene & $71-43-2$ & 0.18 & 0.01 & 7 \\
5 & Toluene & $108-88-3$ & 0.10 & 0.02 & 17 \\
6 & Pentanenitrile & $110-59-8$ & 0.020 & 0.003 & 15 \\
7 & Hexanenitrile & $628-73-9$ & 0.022 & 0.002 & 9 \\
8 & 2-Octanone & $111-13-7$ & 0.039 & 0.018 & 46 \\
\hline \hline
\end{tabular}

1 Results in this table are not quantitative (as defined in Section 4.1) because measured values in at least 1 of the samples are outside instrument callbration limits.

2 CAS $=$ Chemical Abstract Service.

3 Average of $3,55 \mathrm{ml}$ TST samples.

4 RSD = relative standard deviation. Burnum (1995) specifies the RSD should be less than $25 \%$. 
Table $4-4$

Tank BY-108 Positively Identified Organic Compounds in TST Samples for which Practical Holding Times were Exceeded -Analyses by Oak Ridge National Laboratory ${ }^{1}$

\begin{tabular}{clcccc}
\hline $\begin{array}{c}\text { Cmpd } \\
\#\end{array}$ & Compound & $\begin{array}{c}\text { CAS }^{2} \\
\text { Number }\end{array}$ & $\begin{array}{c}\text { Average } \\
(\mathrm{ppmv})\end{array}$ & $\begin{array}{c}\text { Standard } \\
\text { Deviation } \\
\text { (ppmv) }\end{array}$ & $\begin{array}{c}\text { RSD }^{4} \\
(\%)\end{array}$ \\
\hline \hline 1 & Butanal $^{5}$ & $123-72-8$ & 0.87 & 0.66 & 75 \\
2 & 1-Butanol $^{6}$ & $71-36-3$ & 58 & 5 & 8 \\
3 & 2-Pentanone $^{5}$ & $107-87-9$ & 0.46 & 0.07 & 16 \\
\hline \hline
\end{tabular}

1 Practical holding times are defined and discussed in Section 4.1.

2 CAS = Chemical Abstract Service.

3 Average of $3,55 \mathrm{ml}$ TST samples.

4 RSD = relative standard deviation. Burnum (1995) specifies the RSD should be less than $25 \%$.

5 The concentration of this analyte is quantitatively measured (as defined in Section 4.1).

6 The concentration of this analyte was not quantitatively measured (as defined in Section 4.1), because the measured concentration was outside of the instrumental calibration limits. 
WHC-SD-WM-ER-422 REV. 2

Table 4-5

Tank BY-108 Comparison of Organic Compounds in TST and SUMMA ${ }^{\text {TM Samples-- }}$ Analyses by Pacific Northwest Laboratory and Oak Ridge National Laboratory

\begin{tabular}{|c|c|c|c|c|}
\hline Compound & $\begin{array}{c}\mathrm{CAS}^{1} \\
\text { Number }\end{array}$ & $\begin{array}{c}\text { TST } \\
\text { Average }^{2} \\
\text { (ppmv) }\end{array}$ & $\begin{array}{l}\text { SUMMA }^{\mathrm{TM}} \\
\text { Average }^{3} \\
\text { (ppmv) }\end{array}$ & $\begin{array}{r}\text { PRD } \\
(\%)\end{array}$ \\
\hline Ethanenitrile (acetonitriie) & $75-05-8$ & 0.94 & $<0.005$ & $>198$ \\
\hline Propanone (acetone) ${ }^{5}$ & $67-64-1$ & 8.2 & 4.4 & 60 \\
\hline Dichloromethan $e^{5}$ & $75-09-2$ & 1.2 & $<0.005$ & $>198$ \\
\hline Propanenitrile $^{5}$ & $107-12-0$ & 0.048 & $<0.005$ & $>162$ \\
\hline n-Hexane & $110-54-3$ & 2.3 & 1.5 & 42 \\
\hline Benzene & $71-43-2$ & 0.18 & 0.025 & $>151$ \\
\hline Butanenitrile & $109-74-0$ & 0.31 & $<0.005$ & $>194$ \\
\hline n-Heptane & $142-82-5$ & 0.89 & 0.52 & 10 \\
\hline Toluene & $108-88-3$ & 0.10 & 0.045 & 76 \\
\hline Pentanenitrile ${ }^{5}$ & $110-59-8$ & 0.020 & $<0.005$ & $>120$ \\
\hline n-Decane & $124-18-5$ & 0.21 & 0.090 & 80 \\
\hline
\end{tabular}

$1 \mathrm{CAS}=$ Chemical Abstract Service.

2 Average of $3,55 \mathrm{ml}$ TST samples.

3 Average of 3 samples from PNL.

4 PRD = percent relative difference. Keller (1994) requires the PRD to be less than $20 \%$.

5 Two or more of the sample results fell outside the calibration range. 
Table 4-6

Tank BY-108 Tentatively Identified Organic Compounds in SUMMA ${ }^{\text {TM }}$ Samples Analyses by Pacific Northwest Laboratory

\begin{tabular}{|c|c|c|c|c|}
\hline$\underset{\#}{\text { Cmpd }}$ & Compound & $\begin{array}{l}\text { CAS }^{1} \\
\text { Number }\end{array}$ & $\begin{array}{c}\text { Average }{ }^{2} \\
\left(\mathrm{mg} / \mathrm{m}^{3}\right)\end{array}$ & $\begin{array}{c}\text { Standard } \\
\text { Deviation } \\
\left(\mathrm{mg} / \mathrm{m}^{3}\right)\end{array}$ \\
\hline 1 & Propene & $115-07-1$ & 1.82. & 0.04 \\
\hline 2 & Propane & $74-98-6$ & 0.91 & 0.04 \\
\hline 3 & Cyclopropane & $75-19-4$ & 0.29 & 0.00 \\
\hline 4 & Isobutane & $75-28-5$ & 0.58 & 0.02 \\
\hline 5 & 1-Butene & $106-98-9$ & 2.02 & 0.13 \\
\hline 6 & Butane & $106-97-8$ & 1.38 & 0.08 \\
\hline 7 & 2-Methyl-1-Propene & $115-11-7$ & 0.22 & 0.00 \\
\hline 8 & Cyclobutane & $287-23-0$ & 0.40 & 0.01 \\
\hline 9 & Isopropyl Alcohol & $67-63-0$ & 0.22 & 0.01 \\
\hline 10 & 1-Pentene & $109-67-1$ & 0.69 & 0.01 \\
\hline 11 & Pentane & $109-66-0$ & 1.37 & 0.09 \\
\hline 12 & 4-Methyl-1-Pentene & $691-37-2$ & 0.53 & 0.04 \\
\hline 13 & 2-Methylpentane & $107-83-5$ & 2.07 & 0.06 \\
\hline 14 & 3-Methylpentane & $96-14-0$ & 0.40 & 0.01 \\
\hline 15 & 1-Hexene & $592-41-6$ & 0.74 & 0.04 \\
\hline 16 & Methylcyclopentane & $96-37-7$ & 0.28 & 0.01 \\
\hline 17 & 1-Butanol & $71-36-3$ & 12.60 & 0.75 \\
\hline 18 & 2-Pentanone & $107-87-9$ & 1.66 & 0.07 \\
\hline 19 & 3-Methylhexane & $589-34-4$ & 1.69 & 0.05 \\
\hline 20 & 1-Heptene & $592-76-7$ & 1.14 & 0.11 \\
\hline 21 & Unknown C8 Alkene/Cycloalkane & & 0.34 & 0.03 \\
\hline 22 & Unknown C8 Alkane & & 1.26 & 0.03 \\
\hline 23 & 2-Hexanone & $591-78-6$ & 0.66 & 0.04 \\
\hline 24 & Unknown C8 Alkene/Cycloalkane & & 0.21 & 0.01 \\
\hline 25 & 1,2-Dimethylcyclohexane & $583-57-3$ & 0.25 & 0.01 \\
\hline 26 & 1-Octene & $111-66-0$ & 0.31 & 0.01 \\
\hline
\end{tabular}


WHC-SD-WM-ER-422 REV. 2

\begin{tabular}{|c|c|c|c|c|}
\hline$\underset{\#}{C \text { Cmpd }}$ & Compound & $\begin{array}{l}\text { CAS }^{4} \\
\text { Number }\end{array}$ & $\begin{array}{c}\text { Average }^{2} \\
\left(\mathrm{mg} / \mathrm{m}^{3}\right)\end{array}$ & $\begin{array}{c}\text { Standard } \\
\text { Deviation } \\
\left(\mathrm{mg} / \mathrm{m}^{3}\right) \\
\end{array}$ \\
\hline 27 & Octane & $111-65-9$ & 1.36 & 0.05 \\
\hline 28 & 2,6-dimethylheptane & $1072-05-5$ & 0.43 & 0.02 \\
\hline 29 & Unknown Alkene/Cycloalkane & & 0.41 & 0.02 \\
\hline 30 & 2-Heptanone & $110-43-0$ & 0.32 & 0.02 \\
\hline 31 & Nonane & $111-84-2$ & 0.80 & 0.03 \\
\hline 32 & Unknown Ketone & & 0.75 & 0.04 \\
\hline 33 & Unknown C9 Alkene/Cycloalkane & & 0.27 & 0.02 \\
\hline 34 & Unknown C10 Alkane & & 0.25 & 0.01 \\
\hline 35 & 2-Octanone & $111-13-7$ & 0.30 & 0.01 \\
\hline 36 & Unknown C10 Alkene/Cycloalkane & & 0.37 & 0.02 \\
\hline 37 & Unknown C10 Alkene/Cycloalkane & & 0.20 & 0.01 \\
\hline 38 & Unknown C10 Alkene/Cyoloalkane & & 0.24 & 0.01 \\
\hline 39 & Unknown C11 Alkane & & 1.03 & 0.04 \\
\hline 40 & Unknown C11 Alkane & & 0.22 & 0.01 \\
\hline 41 & Unknown C10 Alkene/Cycloalkane & & 0.47 & 0.02 \\
\hline 42 & Unknown C11 Alkane & & 0.22 & 0.01 \\
\hline 43 & Unknown C11 Alkane & & 0.27 & 0.01 \\
\hline 44 & Unknown C11 Alkane & & 0.27 & 0.01 \\
\hline 45 & Decahydronaphthalene & $91-17-8$ & 0.32 & 0.01 \\
\hline 46 & 1-Undecene & $821-95-4$ & 0.32 & 0.03 \\
\hline 47 & Undecane & $1120-21-4$ & 3.34 & 0.13 \\
\hline 48 & Unknown C11 Alkene/Cycloalkane & & 0.60 & 0.04 \\
\hline 49 & Unknown C12 Alkane & & 0.51 & 0.04 \\
\hline 50 & Unknown C12 Alkane & & 0.53 & 0.04 \\
\hline 51 & Naphthalene, decahydro-2-methyl- & $2958-76-1$ & 0.67 & 0.03 \\
\hline 52 & Unknown C11 Alkene/Cycloalkane & & 0.80 & 0.05 \\
\hline 53 & Unknown C12 Alkane & & 0.52 & 0.02 \\
\hline 54 & Decahydro-2-Methylnaphthalene & $2958-76-1$ & 0.30 & 0.01 \\
\hline
\end{tabular}


WHC-SD-WM-ER-422 REV. 2

\begin{tabular}{|c|c|c|c|c|}
\hline$\underset{\#}{\text { Cmpd }}$ & Compound & $\begin{array}{l}\text { CAS }^{1} \\
\text { Number }\end{array}$ & $\begin{array}{l}\text { Average } 2 \\
\left(\mathrm{mg} / \mathrm{m}^{3}\right)\end{array}$ & $\begin{array}{c}\text { Standard } \\
\text { Deviation } \\
\left(\mathrm{mg} / \mathrm{m}^{3}\right) \\
\end{array}$ \\
\hline 55 & Unknown C12 Alkane & & 0.86 & 0.05 \\
\hline 56 & Unknown C12 Alkane & & 0.51 & 0.05 \\
\hline 57 & Unknown Alkyi Decahydronaphthalene & & 0.58 & 0.03 \\
\hline 58 & Dodecane & $112-40-3$ & 6.16 & 0.27 \\
\hline 59 & Unknown C12 Alkene/Cycloalkane & & 0.31 & 0.02 \\
\hline 60 & Decahydro-2,6-Dimethyinaphtalene & $1618-22-0$ & 0.58 & 0.03 \\
\hline 61 & 2,6-Dimethylundecane & $17301-23-4$ & 4.18 & 0.22 \\
\hline 62 & Unknown C13 Alkane & & 0.46 & 0.06 \\
\hline 63 & Unknown Alkyl Decahydronaphthalene & & 0.57 & 0.04 \\
\hline 64 & Unknown C13 Alkene/Cycloalkane & & 2.36 & 0.19 \\
\hline 65 & Unknown Alkyl Decahydronaphthalene & & 0.71 & 0.07 \\
\hline 66 & Unknown C12 Alkane & & 0.98 & 0.12 \\
\hline 67 & Unknown Alkane & & 0.70 & 0.09 \\
\hline 68 & Unknown C14 Alkane & & 4.92 & 0.34 \\
\hline 69 & Unknown C13 Alkene/Cycloalkane & & 0.38 & 0.03 \\
\hline 70 & Tridecane & $629-50-5$ & 5.30 & 0.36 \\
\hline 71 & Unknown C13 Alkene/Cycloalkane & . & 0.33 & 0.03 \\
\hline 72 & Unknown C14 Alkene/Cycloalkane & & 0.91 & 0.06 \\
\hline 73 & Unknown Alkane & & 1.11 & 0.14 \\
\hline 74 & Unknown C14 Alkene/Cycloalkane & & 0.25 & 0.02 \\
\hline 75 & Unknown C13 Alkene/Cycloalkane & & 0.99 & 0.10 \\
\hline 76 & 2-Methyltridecane & $1560-96-9$ & 0.41 & 0.05 \\
\hline 77 & Unknown Alkane & & 0.23 & 0.03 \\
\hline 78 & 2,6,10-Trimethyldodecane, & $3891-98-3$ & 2.43 & 0.24 \\
\hline 79 & Unknown C4 Alkyl Decahydronaphthaiene & & 0.32 & 0.04 \\
\hline 80 & Tetradecane & $629-59-4$ & 1.95 & 0.25 \\
\hline 81 & Unknown C15 Alkene/Cycloalkane & & 0.41 & 0.14 \\
\hline \multicolumn{3}{|c|}{ Sum of tentatively identified compounds: } & 89.0 & \\
\hline
\end{tabular}


WHC-SD-WM-ER-422 REV. 2

$1 \mathrm{CAS}=$ Chemical Abstract Number.

2 Average of 3 samples, values listed are estimates. 
Table 4-7

Tank BY-108 Tentatively Identified Organic Compounds in TST Samples in the Order of Chromatographic Elution -Analyses by Oak Ridge National Laboratory

\begin{tabular}{|c|c|c|c|c|}
\hline$\underset{\#}{\text { Cmpd }}$ & Compound & $\begin{array}{c}\text { CAS }^{1} \\
\text { Number }\end{array}$ & $\begin{array}{l}\text { Average }^{2} \\
\left(\mathrm{mg} / \mathrm{m}^{3}\right)\end{array}$ & $\begin{array}{l}\text { Standard } \\
\text { Deviation } \\
\left(\mathrm{mg} / \mathrm{m}^{3}\right)\end{array}$ \\
\hline 1 & 1-propene, 2-methyl- & $115-11-7$ & 1.6 & 1.5 \\
\hline 2 & 1-propene, 2-methyl- & $115-11-7$ & 2.1 & 0.4 \\
\hline 3 & 1-propene, 2-methyl- & $115-11-7$ & 0.48 & 0.84 \\
\hline 4 & 1-butene, 3-methyl- & $563-45-1$ & 0.51 & 0.88 \\
\hline 5 & butane, 2-methyl- & $78-78-4$ & 7.9 & 0.8 \\
\hline 6 & methane, trichlorofluro- & $75-69-4$ & 11.9 & 13.0 \\
\hline 7 & cyclopropane, ethyl- & $1191-96-4$ & 7.3 & 0.8 \\
\hline 8 & 3-buten-1-ol & $627-27-0$ & 6.1 & 10.5 \\
\hline 9 & furan & $110-00-9$ & 0.55 & 0.96 \\
\hline 10 & oxirane, ethenyl- & $930-22-3$ & 0.8 & 1.4 \\
\hline 11 & 2-propanol & $67-63-0$ & 5.3 & 1.6 \\
\hline 12 & 2-pentene, (Z)- & $627-20-3$ & 0.88 & 0.76 \\
\hline 13 & cyclobutane, methyl- & $598-61-8$ & 0.92 & 0.80 \\
\hline 14 & 1-pentene, 4-methyl- & $691-37-2$ & 2.5 & 0.3 \\
\hline 15 & pentane, 2-methyl- & $107-83-5$ & 15.1 & 0.9 \\
\hline 16 & 1-propene, 2-fluoro- & $1184-60-7$ & 0.47 & 0.82 \\
\hline 17 & pentane, 3-methyl- & $96-14-0$ & 2.5 & 0.2 \\
\hline 18 & 1-pentene, 2-methyl- & $763-29-1$ & 2.6 & 1.6 \\
\hline 19 & 1-hexene & $592-41-6$ & 3.0 & 2.6 \\
\hline 20 & 2-butanone & $78-93-3$ & 0.66 & 1.14 \\
\hline 21 & cyclopentane, methyl- & $96-37-7$ & $2.1^{\circ}$ & 0.3 \\
\hline 22 & furan, tetrahydro- & $109-99-9$ & 8.5 & 2.0 \\
\hline 23 & 1,3-pentadiene, 2-methyi- & $1118-58-7$ & 0.49 & 0.85 \\
\hline 24 & 1-pentene, 3,4-dimethyl- & $7385-78-6$ & 0.59 & 1.02 \\
\hline 25 & 1-hexene, 5-methyl- & 3524-73-0 & 0.53 & 0.91 \\
\hline 26 & hexane, 2-methyl- & $591-76-4$ & 1.34 & 0.05 \\
\hline
\end{tabular}




\begin{tabular}{|c|c|c|c|c|}
\hline Cmpd & Compound & $\begin{array}{c}\mathrm{CAS}^{1} \\
\text { Number }\end{array}$ & $\begin{array}{l}\text { Average }^{2} \\
\left(\mathrm{mg} / \mathrm{m}^{3}\right)\end{array}$ & $\begin{array}{c}\text { Standard } \\
\text { Deviation } \\
\left(\mathrm{mg} / \mathrm{m}^{3}\right)\end{array}$ \\
\hline 27 & cyclopentane, 1,2-dimethyl-, trans- & $822-50-4$ & 0.324 & 0.305 \\
\hline 28 & cyclopropane, butyl- & $930-57-4$ & 2.5 & 0.3 \\
\hline 29 & 2-heptene & $592-77-8$ & 0.16 & 0.28 \\
\hline 30 & cyclohexane, methyl- & $108-87-2$ & 1.13 & 0.06 \\
\hline 31 & mixture & & 0.14 & 0.24 \\
\hline 32 & propane, 2-nitro \& others & & 0.14 & 0.23 \\
\hline 33 & 1-heptene, 6-methyl- & $5026-76-6$ & 0.25 & 0.43 \\
\hline 34 & 1-heptene, 3-methyl- & $4810-09-7$ & 0.52 & 0.46 \\
\hline 35 & heptane, 2,3,5-trimethy:- & 20278-85-7 & 0.65 & 1.12 \\
\hline 36 & heptane, 2,3,6-trimethyi- & $4032-93-3$ & 1.26 & 1.10 \\
\hline 37 & 1-octene & $111-66-0$ & 0.74 & 0.65 \\
\hline 38 & heptane, 3-methyl- & $589-81-1$ & 0.19 & 0.32 \\
\hline 39 & 3-pentanol, 2-methyl- and others & & 0.11 & 0.19 \\
\hline 40 & cyclohexane, 1,3-dimethyl-, cis- & $638-04-0$ & 0.11 & 0.20 \\
\hline 41 & cyclopentane, 1,1,3-trimethyl- & . $\quad 4516-69-2$ & 0.24 & 0.21 \\
\hline 42 & hexanal, 3-methyl- & $19269-28-4$ & 0.24 & 0.42 \\
\hline 43 & 1-octene & $111-66-0$ & 0.18 & 0.31 \\
\hline 44 & 2H-pyran-2-one, tetrahydro-5,6-dimethyl- & $24405-16-1$ & 0.81 & 0.72 \\
\hline 45 & 1-octanol & $111-87-5$ & 0.12 & 0.20 \\
\hline 46 & hexamethylcyclotrisiloxane & $541-05-9$ & 0.13 & 0.22 \\
\hline 47 & heptane, 2,6-dimethyl- & $1072-05-5$ & 0.56 & 0.07 \\
\hline 48 & cyclohexane, ethyl- & $1678-91-7$ & 0.46 & 0.11 \\
\hline 49 & cyclohexane, 1,1,3-trimethyl- & $3073-66-3$ & 0.82 & 0.19 \\
\hline 50 & 1-nonene & $124-11-8$ & 0.31 & 0.27 \\
\hline 51 & heptane, 2,3-dimethyl- & $3074-71-3$ & 0.09 & 0.16 \\
\hline 52 & benzene, ethyl and octane, 2-methyl- & & 0.54 & 0.05 \\
\hline 53 & benzene, 1,2-dimethyl- & $95-47-6$ & 0.40 & 0.69 \\
\hline 54 & benzene, 1,4-dimethyl- & $106-42-3$ & 0.35 & 0.61 \\
\hline
\end{tabular}




\begin{tabular}{|c|c|c|c|c|}
\hline$\underset{\#}{\mathrm{Cmpd}}$ & Compound & $\begin{array}{c}\text { CAS }^{1} \\
\text { Number }\end{array}$ & $\begin{array}{l}\text { Average }^{2} \\
\left(\mathrm{mg} / \mathrm{m}^{3}\right)\end{array}$ & $\begin{array}{c}\text { Standard } \\
\text { Deviation } \\
\left(\mathrm{mg} / \mathrm{m}^{3}\right)\end{array}$ \\
\hline 55 & heptane, 3,5-dimethyl- & $926-82-9$ & 0.073 & 0.126 \\
\hline 56 & octane, 3-methyi- and c2-benzene & & 0.43 & 0.74 \\
\hline 57 & butane, 1,1'-oxybis- & $142-96-1$ & 0.17 & 0.15 \\
\hline 58 & 3-heptanone & $106-35-4$ & 0.68 & 0.10 \\
\hline 59 & benzene, 1,2-dimethyi- & $95-47-6$ & 0.38 & 0.06 \\
\hline 60 & mixture & & 0.069 & 0.119 \\
\hline 61 & cyclohexane, 1-ethyl-4-methyl-, trans- & $6236-88-0$ & 0.057 & 0.099 \\
\hline 62 & 3,4-nonadiene & $37050-03-6$ & 0.48 & 0.14 \\
\hline 63 & heptane, 4-(1-methylethyl)- & $52896-87-4$ & 0.15 & 0.26 \\
\hline 64 & 1-hexene, 4,5-dimethyl- & $16106-59-5$ & 0.11 & 0.20 \\
\hline 65 & 4-nonyne & 20184-91-2 & 0.13 & 0.23 \\
\hline 66 & 2-heptanone, 6-methyl- & $928-68-7$ & 1.4 & 0.6 \\
\hline 67 & nonane, 4-methyl- & $17301-94-9$ & 0.57 & 0.25 \\
\hline 68 & cyclohexane, 1,1,4,4-tetramethyl- & & 0.41 & 0.12 \\
\hline 69 & 2-octanol & $123-96-6$ & 0.40 & 0.20 \\
\hline 70 & 3-buten-2-ol & $598-32-3$ & 4.8 & 3.9 \\
\hline$\cdot 71$ & 2-heptyl furan & & 0.22 & 0.23 \\
\hline 72 & cyclohexane, 1-methyl-4-(1-methylethyl) \& other & & 0.099 & 0.170 \\
\hline 73 & $\begin{array}{l}\text { cyclopentanone,2-methyl-4-(2-methyl- } \\
\text { propyl) }\end{array}$ & $69770-96-3$ & 0.16 & 0.27 \\
\hline 74 & cyclopentane,2-isopropyl-1,3-dimethyl- & $32281-85-9$ & 0.25 & 0.44 \\
\hline 75 & cyclohexane, 1-methyl-4-(1-methylethyl)cis & $6069-98-3$ & 0.23 & 0.22 \\
\hline 76 & cyclopentane, 1-methyl-3-(2-methylpropyl) & 29053-04-1 & 0.57 & 0.16 \\
\hline 77 & cyclotetrasiloxane, octamethyl- & $556-67-2$ & 1.1 & 0.9 \\
\hline 78 & cyclohexane, 1,5-diethyl-2,3-dimethyl- & $74663-66-4$ & 0.52 & 0.25 \\
\hline 79 & nonane, 2,6-dimethyl- & $17302-28-2$ & 2.2 & 1.1 \\
\hline 80 & octane, 6-ethyl-2-methyl- & $62016-19-7$ & 0.19 & 0.20 \\
\hline 81 & 1,4-pentadiene, 2,3,4-trimethyl- \& others &. & 0.079 & 0.137 \\
\hline 82 & 3-decyne & 2384-85-2 & 0.51 & 0.17 \\
\hline
\end{tabular}




\begin{tabular}{|c|c|c|c|c|}
\hline$\underset{\#}{\text { Cmpd }}$ & Compound & $\begin{array}{c}\text { CAS }^{1} \\
\text { Number }\end{array}$ & $\begin{array}{l}\text { Average }^{2} \\
\left(\mathrm{mg} / \mathrm{m}^{3}\right)\end{array}$ & $\begin{array}{c}\text { Standard } \\
\text { Deviation } \\
\left(\mathrm{mg} / \mathrm{m}^{3}\right)\end{array}$ \\
\hline 83 & cyclohexane, butyl- & $1678-93-9$ & 1.46 & 0.39 \\
\hline 84 & cyclohexane, 1-ethyl-4-methyl, cis & $4926-78-7$ & 0.16 & 0.14 \\
\hline 85 & cyclohexaen, cyclopropyl- & $32669-86-6$ & 0.19 & 0.17 \\
\hline 86 & 1-ethyl-2,2,6-trimethylcyclohexane & & 0.55 & 0.14 \\
\hline 87 & decane, 5-methyl- & $13151-35-4$ & 0.73 & 0.20 \\
\hline 88 & decane, 4-methyl- & $2847-72-5$ & 0.78 & 0.21 \\
\hline 89 & decane, 2-methyl- & $6975-98-0$ & 1.8 & 0.5 \\
\hline 90 & naphthalene, decahydro-, trans- & 493-02-7 & 1.1 & 0.3 \\
\hline 91 & decane, 3-methyl- & $13151-34-3$ & 1.1 & 0.2 \\
\hline 92 & cyclohexane, 1,2-diethyl-3-methyl- & $61141-80-8$ & 0.47 & 0.12 \\
\hline 93 & formic acid, 2,6-dimethyl-5-hepten-2-ol ester & & 0.37 & 0.10 \\
\hline 94 & $\begin{array}{l}\text { cyclohexane,1-(cyclohexyimethyl)-4-methy } \\
\text { l- }\end{array}$ & $66826-95-7$ & 0.80 & 0.19 \\
\hline 95 & c5-cyciohexane & & 0.69 & 0.14 \\
\hline 96 & 5-undecene & $4941-53-1$ & 1.0 & 0.3 \\
\hline 97 & 2-nonanone and others & $821-55-6$ & 0.93 & 0.23 \\
\hline 98 & cyclohexane, 1-ethyl-2-propyl- & $62238-33-9$ & 0.28 & 0.26 \\
\hline 99 & 5-undecene & $4941-53-1$ & 0.49 & 0.13 \\
\hline 100 & 1-undecene, 4-methyl- & $74630-39-0$ & 0.51 & 0.89 \\
\hline 101 & nonane, 3,7-dimethyl- & $17302-32-8$ & 0.80 & 1.39 \\
\hline 102 & undecane, 5-methyl- & $1632-70-8$ & 2.9 & 0.8 \\
\hline 103 & bicyclo[4.1.0]heptane, 3-methyl-7-pentyl- & & 0.41 & 0.09 \\
\hline 104 & undecane, 4-methyl- & $2980-69-0$ & 0.36 & 0.09 \\
\hline 105 & naphthalene, decahydro-2-methyl- & $2958-76-1$ & 2.2 & 0.6 \\
\hline 106 & undecane, 3,8-dimethyl- & $17301-30-3$ & 1.0 & 0.9 \\
\hline 107 & undecane, 4,7-dimethyl- & $17301-32-5$ & 0.77 & 1.34 \\
\hline 108 & dimethyl-decahydronaphthalene & & 0.25 & 0.24 \\
\hline 109 & 2-undecene, 8-methyl- & $74630-44-7$ & 0.38 & 0.12 \\
\hline 110 & 1-dodecene & $112-41-4$ & 0.38 & 0.08 \\
\hline
\end{tabular}




\begin{tabular}{|c|c|c|c|c|}
\hline$\underset{\#}{\text { Cmpd }}$ & Compound & $\begin{array}{c}\text { CAS }^{1} \\
\text { Number }\end{array}$ & $\begin{array}{c}\text { Average } \\
\left(\mathrm{mg} / \mathrm{m}^{3}\right)\end{array}$ & $\begin{array}{c}\text { Standard } \\
\text { Deviation } \\
\left(\mathrm{mg} / \mathrm{m}^{3}\right) \\
\end{array}$ \\
\hline 111 & cyclopentane, (2-methylbutyl)- & $53366-38-4$ & 0.35 & 0.10 \\
\hline 112 & naphthalene, decahydro-2-methyl & $2958-76-1$ & 5.9 & 1.6 \\
\hline 113 & 3-dodecene, (Z)- & $7239-23-8$ & 0.20 & 0.19 \\
\hline 114 & naphthalene, decahydro-2-methyl- & $2958-76-1$ & 0.21 & 0.19 \\
\hline 115 & 6-methylundecane & $17302-33-9$ & 3.4 & 0.9 \\
\hline 116 & undecane, 4-methyl- & $2980-69-0$ & 1.9 & 0.5 \\
\hline 117 & undecane, 2-methyl- & $7045-71-8$ & 3.8 & 1.0 \\
\hline 118 & undecane, 2,3-dimethyl- & $17312-77-5$ & 0.97 & 0.28 \\
\hline 119 & undecane, 3-methyl- & $1002-43-3$ & 2.1 & 0.6 \\
\hline 120 & 4-undecene, 4-methyl- & $61142-40-3$ & 0.86 & 0.18 \\
\hline 121 & decane, 2,3,6- trimethyl- & $62238-12-4$ & 0.7 .1 & 0.18 \\
\hline 122 & cyclododecane & $294-62-2$ & 1.4 & 0.3 \\
\hline 123 & naphthalene, decahydro-2,6-dimethyl- & $1618-22-0$ & 1.4 & 0.3 \\
\hline 124 & naphthalene, decahydro-2,3-dimethyl- & $1008-80-6$ & 0.11 & 0.11 \\
\hline 125 & cyclohexane, 1-methyl-2-pentyl- & $54411-01-7$ & 0.53 & 0.11 \\
\hline 126 & 5-heptenal, 2,6-dimethyl- & $106-72-9$ & 0.42 & 0.11 \\
\hline 127 & undecane, 2,4-dimethyl- & $17312-80-0$ & 0.16 & 0.15 \\
\hline 128 & undecane, 2,6-dimethyl- & $17301-23-4$ & 7.5 & 1.7 \\
\hline 129 & undecane, 2,7-dimethyl- & $17301-24-5$ & 0.40 & 0.37 \\
\hline 130 & undecane, 3,7-dimethyl- & $17301-29-0$ & 0.24 & 0.42 \\
\hline 131 & dimethyl-decahydronaphthalene & & 1.0 & 0.2 \\
\hline 132 & cyclopentane, 1-pentyl-2-propyl- & $62199-51-3$ & 0.26 & 0.05 \\
\hline 133 & cyclohexane, 2-butyl-1,1,3-trimethyl- & $54676-39-0$ & 3.0 & 0.6 \\
\hline 134 & 1-octanol, 2-butyl- & $3913-02-8$ & 0.35 & 0.08 \\
\hline 135 & naphthalene, decahydro-1,6-dimethyl- & $1750-51-2$ & 0.36 & 0.08 \\
\hline 136 & $(E, E)(3 S, 8 S), 3,8$-dimethyldeca-4,6-diene & & 0.47 & 0.10 \\
\hline 137 & cyclohexane, (4-methylpentyi)- & $61142-20-9$ & 2.7 & 0.5 \\
\hline 138 & dodecane, 6-methyi- & $6044-71-9$ & 0.80 & 0.15 \\
\hline
\end{tabular}


WHC-SD-WM-ER-422 REV. 2

\begin{tabular}{|c|c|c|c|c|}
\hline$\underset{\#}{\text { Cmpd }}$ & Compound & $\begin{array}{l}\text { CAS }^{1} \\
\text { Number }\end{array}$ & $\begin{array}{l}\text { Average } \\
\left(\mathrm{mg} / \mathrm{m}^{3}\right)\end{array}$ & $\begin{array}{c}\text { Standard } \\
\text { Deviation } \\
\left(\mathrm{mg} / \mathrm{m}^{3}\right)\end{array}$ \\
\hline 139 & dodecane, 5-methyl- & $17453-93-9$ & 0.57 & 0.12 \\
\hline 140 & dodecane, 4-methyl- & $6117-97-1$ & 1.8 & 0.4 \\
\hline 141 & undecane, 2,10-dimethyi- & $17301-27-8$ & 3.3 & 0.7 \\
\hline 142 & mixture & & 0.45 & 0.10 \\
\hline 143 & dodecane, 4,6-dimethyl- & $61141-72-8$ & 6.4 & 6.1 \\
\hline 144 & cyclohexane, 2,4-diethyl-1-methyl- & $61142-70-9$ & 0.15 & 0.14 \\
\hline 145 & tridecane, 7-methyl- & $26730-14-3$ & 3.9 & 6.8 \\
\hline 146 & $\begin{array}{l}2(3 \mathrm{H}) \text {-benzofuranone, } 3 \mathrm{a}, 4,5,6 \text { tetrahydro-3a } \\
6,6 \text {-trimethyl- }\end{array}$ & $16778-26-0$ & 0.73 & 0.20 \\
\hline 147 & cyclohexane, 1,2-diethyl-1-methyl- & $61141-79-5$ & 0.24 & 0.25 \\
\hline 148 & 6-tridecene, 7-methyl- & $24949-42-6$ & 2.3 & 0.7 \\
\hline 149 & 5-tetradecene, (E)- & $41446-66-6$ & 0.63 & 0.17 \\
\hline 150 & tridecane, 5-methyl- & $25117-31-1$ & 0.32 & 0.31 \\
\hline 151 & undecane, 4,6-dimethyl- & $17312-82-2$ & 0.47 & 0.44 \\
\hline 152 & tetradecane & $629-59-4$ & 0.22 & 0.38 \\
\hline 153 & undecane, 6,6-dimethyl- & $17312-76-4$ & 0.30 & 0.51 \\
\hline 154 & dodecane, 2,5-dimethyl- & $56292-65-0$ & 2.5 & 0.7 \\
\hline 155 & cyclopentane, 1-hexyl-3-methyl- & $61142-68-5$ & 0.093 & 0.087 \\
\hline 156 & cyclohexane, 1-(cyclohexylmethyl)-2-ethyl- & $54934-93-9$ & 0.31 & 0.10 \\
\hline 157 & 4-nonene, 2,3,3-trimethyi-, (E)- & $63830-68-2$ & 0.57 & 0.16 \\
\hline 158 & naphthalene, 2-butyldecahydro- & $6305-52-8$ & 0.32 & 0.09 \\
\hline 159 & tetradecane & $629-59-4$ & 1.0 & 0.3 \\
\hline 160 & octane, 2-cyclohexyl- & $2883-05-8$ & 2.6 & 0.8 \\
\hline 161 & tridecane, 4-methyl- & $26730-12-1$ & 1.5 & 0.4 \\
\hline 162 & tridecane, 2-methyi- & $1560-96-9$ & 2.0 & 0.6 \\
\hline 163 & undecane, 4,6-dimethyl- & $17312-82-2$ & 0.037 & 0.064 \\
\hline 164 & decane, 2,3,5,8-tetramethyl- & & 0.052 & 0.091 \\
\hline 165 & cyclohexane, 1-(cyclohexyimethyl)-2-ethyl- & $54934-93-9$ & 0.70 & 0.20 \\
\hline 166 & tridecane, 3-methyl- & $6418-41-3$ & 0.25 & 0.44 \\
\hline
\end{tabular}


WHC-SD-WM-ER-422 REV. 2

\begin{tabular}{|c|c|c|c|c|}
\hline$\underset{\#}{\text { Cmpd }}$ & Compound & $\begin{array}{c}\mathrm{CAS}^{1} \\
\text { Number }\end{array}$ & $\begin{array}{c}\text { Average }^{2} \\
\left(\mathrm{mg} / \mathrm{m}^{3}\right)\end{array}$ & $\begin{array}{c}\text { Standard } \\
\text { Deviation } \\
\left(\mathrm{mg} / \mathrm{m}^{3}\right)\end{array}$ \\
\hline 167 & dodecane, 3-methyl- & $17312-57-1$ & 0.87 & 0.75 \\
\hline 168 & dodecane, 2,6,10-trimethyl- & $3891-98-3$ & 7.3 & 2.1 \\
\hline 169 & cyclohexane, (2,2-dimethylcyclopentyl)- & $61142-23-2$ & 0.027 & 0.047 \\
\hline 170 & $\begin{array}{l}\text { cyclohexane, } \\
\text { 1-(cyclohexylmethyl)-2-methyl- }\end{array}$ & $54823-94-8$ & 0.25 & 0.07 \\
\hline 171 & tetradecane & $629-59-4$ & 7.3 & 2.0 \\
\hline 172 & tridecane, 4,8-dimethyl- & $55030-62-1$ & 1.5 & 1.4 \\
\hline 173 & tridecane, 3-ethyl- & $13286-73-2$ & 0.089 & 0.154 \\
\hline 174 & pentadecane & $629-62-9$ & 1.2 & 1.7 \\
\hline 175 & pentadecane & $629-62-9$ & 0.32 & 0.55 \\
\hline 176 & alkyl-cyclohexane & . & 0.45 & 0.15 \\
\hline 177 & heptadecane, 7-methyl- & $20959-33-5$ & 0.17 & 0.29 \\
\hline 178 & c15-alkane & & 0.14 & 0.16 \\
\hline 179 & c15-alkane & & 0.16 & 0.15 \\
\hline 180 & decane, $1,1^{\prime}$-oxybis- & $2456-28-2$ & 0.65 & 0.63 \\
\hline 181 & 1-octadecanol & $112-92-5$ & 0.45 & 0.78 \\
\hline 182 & dodecane, 2-methyl-8-propyl- & $55045-07-3$ & 2.9 & 0.8 \\
\hline 183 & pentadecane, 2-methyl- & $1560-93-6$ & 0.18 & 0.17 \\
\hline 184 & tetradecane, 3-methyl- & $18435-22-8$ & 0.13 & 0.22 \\
\hline 185 & hexadecane, 2,6,10,14-tetramethyl- & $638-36-8$ & 0.091 & 0.080 \\
\hline 186 & 7-hexadecene, $(Z)$ - & $35507-09-6$ & 0.22 & 0.06 \\
\hline 187 & 2-pentanone, 4-cyclohexayliden-3,3-diethyl- & & 0.11 & 0.10 \\
\hline 188 & pentadecane & $629-62-9$ & 1.6 & 0.5 \\
\hline 189 & dodecanoic acid & $143-07-7$ & 0.31 & 0.10 \\
\hline 190 & hexadecane & $544-76-3$ & 0.053 & 0.092 \\
\hline 191 & benzenamine, N-phenyl- & $122-39-4$ & 0.23 & 0.06 \\
\hline 192 & tetradecanoic acid & $544-63-8$ & 2.1 & 1.7 \\
\hline 193. & hexacosane & $630-01-3$ & 0.099 & 0.172 \\
\hline 194 & benzenesulfonamide, N-butyl- & $3622-84-2$ & 1.5 & 0.7 \\
\hline
\end{tabular}


WHC-SD-WM-ER-422 REV. 2

\begin{tabular}{llrcc}
\hline $\begin{array}{c}\text { Cmpd } \\
\#\end{array}$ & Compound & $\begin{array}{c}\mathrm{CAS}^{1} \\
\text { Number }\end{array}$ & $\begin{array}{c}\text { Average } \\
\left(\mathrm{mg} / \mathrm{m}^{3}\right)\end{array}$ & $\begin{array}{c}\text { Standard } \\
\text { Deviation } \\
\left(\mathrm{mg}^{3} \mathrm{~m}^{3}\right)\end{array}$ \\
\hline \hline 195 & pentadecanoic acid & $1002-84-2$ & 0.36 & 0.14 \\
196 & 1-hexadecanol & $36653-82-4$ & 0.097 & 0.174 \\
197 & 1-hexadecene & $629-73-2$ & 0.049 & 0.085 \\
198 & alkane & & 0.53 & 0.92 \\
199 & alkane & $2091-29-4$ & 0.32 & 3.6 \\
200 & 9-hexadecenoic acid & $57-10-3$ & 1.4 & 0.31 \\
201 & hexadecanoic acid & & 0.081 & 1.4 \\
202 & phthalate & $142-91-6$ & 0.44 & 0.140 \\
203 & hexadecanoic acid, 1-methylethyl ester & $2136-70-1$ & 0.70 & -0.31 \\
204 & ethanol, 2-(tetradecyloxy)- & & 0.09 & 1.22 \\
205 & alkane & & 0.23 & -0.15 \\
206 & 5-eicosane, (E) & & 0.39 \\
207 & 1-hexadecene & $74685-30-6$ & 0.25 & 0.43 \\
208 & octadecane & $629-73-2$ & 0.25 & 0.043 \\
\hline \hline Sum of tentatively identified compounds: & $593-45-3$ & 0.025 & 251.9 \\
\hline \hline
\end{tabular}

$1 \mathrm{CAS}=$ Chemical Abstract Service

2 Average of $3,55 \mathrm{ml}$ TST samples, values listed are estimates. 
WHC-SD-WM-ER-422 REV. 2

Table 4-8

Tank BY-108 Tentatively Identified Organic Compounds in TST Samples Sorted Alphanumerically -Analyses by Oak Ridge National Laboratory

\begin{tabular}{|c|c|c|c|c|}
\hline$\underset{\#}{C m p d}$ & Compound & $\begin{array}{c}\mathrm{CAS}^{1} \\
\text { Number }\end{array}$ & $\begin{array}{l}\text { Average } 2 \\
\left(\mathrm{mg} / \mathrm{m}^{3}\right)\end{array}$ & $\begin{array}{c}\text { Standard } \\
\text { Deviation } \\
\left(\mathrm{mg} / \mathrm{m}^{3}\right) \\
\end{array}$ \\
\hline 136 & $(E, E)(3 S, 8 S), 3,8$-dimethyldeca-4,6-diene & & 0.47 & 0.10 \\
\hline 2 & 1-propene, 2-methyl- & $115-11-7$ & 2.1 & 0.4 \\
\hline 3 & 1-propene, 2-methyl- & $115-11-7$ & 0.48 & 0.84 \\
\hline 4 & 1-butene, 3-methyl- & $563-45-1$ & 0.51 & 0.88 \\
\hline 1 & 1-propene, 2-methyl- & $115-11-7$ & 1.6 & 1.5 \\
\hline 64 & 1-hexene, 4,5-dimethyl- & $16106-59-5$ & 0.11 & 0.20 \\
\hline 45 & 1-octanol & $111-87-5$ & 0.12 & 0.20 \\
\hline 100 & 1-undecene, 4-methyl- & $74630-39-0$ & 0.51 & 0.89 \\
\hline 134 & 1-octanol, 2-butyl- & $3913-02-8$ & 0.35 & 0.08 \\
\hline 207 & 1-hexadecene & $629-73-2$ & 0.25 & 0.43 \\
\hline 37 & 1-octene & $111-66-0$ & 0.74 & 0.65 \\
\hline 86 & 1-ethyl-2,2,6-trimethylcyclohexane & & 0.55 & 0.14 \\
\hline 181 & 1-octadecanol & $112-92-5$ & 0.45 & 0.78 \\
\hline 14 & 1-pentene, 4-methyl- & $691-37-2$ & 2.5 & 0.3 \\
\hline 196 & 1-hexadecanol & $36653-82-4$ & 0.097 & 0.174 \\
\hline 16 & 1-propene, 2-fluoro- & $1184-60-7$ & 0.47 & 0.82 \\
\hline 197 & 1-hexadecene & $629-73-2$ & 0.049 & 0.085 \\
\hline 18 & 1-pentene, 2-methyl- & $763-29-1$ & 2.6 & 1.6 \\
\hline 19 & 1-hexene & $592-41-6$ & 3.0 & 2.6 \\
\hline 34 & 1-heptene, 3-methyl- & $4810-09-7$ & 0.52 & 0.46 \\
\hline 110 & 1-dodecene & $112-41-4$ & 0.38 & 0.08 \\
\hline 43 & 1-octene & $111-66-0$ & 0.18 & 0.31 \\
\hline 33 & 1-heptene, 6-methyl- & $5026-76-6$ & 0.25 & 0.43 \\
\hline 24 & 1-pentene, 3,4-dimethyl- & $7385-78-6$ & 0.59 & 1.02 \\
\hline 25 & 1-hexene, 5-methyl- & $3524-73-0$ & 0.53 & 0.91 \\
\hline 50 & 1-nonene & $124-11-8$ & 0.31 & 0.27 \\
\hline
\end{tabular}




\begin{tabular}{|c|c|c|c|c|}
\hline$\underset{\#}{\text { Cmpd }}$ & Compound & $\begin{array}{c}\mathrm{CAS}^{1} \\
\text { Number }\end{array}$ & $\begin{array}{l}\text { Average }^{2} \\
\left(\mathrm{mg} / \mathrm{m}^{3}\right)\end{array}$ & $\begin{array}{l}\text { Standard } \\
\text { Deviation } \\
\left(\mathrm{mg} / \mathrm{m}^{3}\right)\end{array}$ \\
\hline 23 & 1,3-pentadiene, 2-methyl- & $1118-58-7$ & 0.49 & 0.85 \\
\hline 81 & 1,4-pentadiene, 2,3,4-trimethyl- \& others & & 0.079 & 0.137 \\
\hline 29 & 2-heptene & $592-77-8$ & 0.16 & 0.28 \\
\hline 109 & 2-undecene, 8-methyl- & $74630-44-7$ & 0.38 & 0.12 \\
\hline 97 & 2-nonanone and others & $821-55-6$ & 0.93 & 0.23 \\
\hline 187 & 2-pentanone, 4-cyclohexayliden-3,3-diethyl- & & 0.11 & 0.10 \\
\hline 66 & 2-heptanone, 6-methyl- & $928-68-7$ & 1.4 & 0.6 \\
\hline 20 & 2-butanone & $78-93-3$ & 0.66 & 1.14 \\
\hline 69 & 2-octanol & $123-96-6$ & 0.40 & 0.20 \\
\hline 12 & 2-pentene, (Z)- & $627-20-3$ & 0.88 & 0.76 \\
\hline 11 & 2-propanol & $67-63-0$ & 5.3 & 1.6 \\
\hline 71 & 2-heptyl furan & & 0.22 & 0.23 \\
\hline 146 & $\begin{array}{l}\text { 2(3H)-benzofuranone, } 3 a, 4,5,6 \text { tetrahydro-3a, } \\
6,6 \text {-trimethyl- }\end{array}$ & $16778-26-0$ & 0.73 & 0.20 \\
\hline 44 & 2H-pyran-2-one, tetrahydro-5,6-dimethyl- & $24405-16-1$ & 0.81 & 0.72 \\
\hline 39 & 3-pentanol, 2-methyl- and others & & 0.11 & 0.19 \\
\hline 58 & 3-heptanone & $106-35-4$ & 0.68 & 0.10 \\
\hline 113 & 3-dodecene, (Z)- & $7239-23-8$ & 0.20 & 0.19 \\
\hline 8 & 3-buten-1-ol & $627-27-0$ & 6.1 & 10.5 \\
\hline 70 & 3-buten-2-ol & $598-32-3$ & 4.8 & 3.9 \\
\hline 82 & 3-decyne & $2384-85-2$ & 0.51 & 0.17 \\
\hline 62 & 3,4-nonadiene & $37050-03-6$ & 0.48 & 0.14 \\
\hline 157 & 4-nonene, 2,3,3-trimethyl-, (E)- & $63830-68-2$ & 0.57 & 0.16 \\
\hline 120 & 4-undecene, 4-methyl- & $61142-40-3$ & 0.86 & 0.18 \\
\hline 65 & 4-nonyne & $20184-91-2$ & 0.13 & 0.23 \\
\hline 149 & 5-tetradecene, $(\boldsymbol{E})$ - & $41446-66-6$ & 0.63 & 0.17 \\
\hline 99 & 5-undecene & $4941-53-1$ & 0.49 & 0.13 \\
\hline 206 & 5-eicosane, (E) & $74685-30-6$ & 0.23 & 0.39 \\
\hline 96 & 5-undecene & $4941-53-1$ & 1.0 & 0.3 \\
\hline
\end{tabular}




\begin{tabular}{|c|c|c|c|c|}
\hline$\underset{\#}{C \text { Cmpd }}$ & Compound & $\begin{array}{c}\mathrm{CAS}^{1} \\
\text { Number }\end{array}$ & $\begin{array}{c}\text { Average } \\
\left(\mathrm{mg} / \mathrm{m}^{3}\right)\end{array}$ & $\begin{array}{c}\text { Standard } \\
\text { Deviation } \\
\left(\mathrm{mg} / \mathrm{m}^{3}\right)\end{array}$ \\
\hline 126 & 5-heptenal, 2,6-dimethyl- & $106-72-9$ & 0.42 & 0.11 \\
\hline 148 & 6-tridecene, 7-methyl- & $24949-42-6$ & 2.3 & 0.7 \\
\hline 115 & 6-methylundecane & $17302-33-9$ & 3.4 & 0.9 \\
\hline 186 & 7-hexadecene, (Z)- & $35507-09-6$ & 0.22 & 0.06 \\
\hline 200 & 9-hexadecenoic acid & $2091-29-4$ & 0.32 & 0.31 \\
\hline 198 & alkane & & 0.53 & 0.92 \\
\hline 199 & alkane & & 2.2 & 3.6 \\
\hline 205 & alkane & & 0.09 & 0.15 \\
\hline 176 & alkyl-cyclohexane & & 0.45 & 0.15 \\
\hline 191 & benzenamine, $\mathrm{N}$-phenyl- & $122-39-4$ & 0.23 & 0.06 \\
\hline 52 & benzene, ethyl and octane, 2-methyl- & & 0.54 & 0.05 \\
\hline 53 & benzene, 1,2-dimethyl- & $95-47-6$ & 0.40 & 0.69 \\
\hline 54 & benzene, 1,4-dimethyl- & $106-42-3$ & 0.35 & 0.61 \\
\hline 59 & benzene, 1,2-dimethyl- & $95-47-6$ & 0.38 & 0.06 \\
\hline 194 & benzenesulfonamide, $\mathrm{N}$-butyl- & $3622-84-2$ & 1.5 & 0.7 \\
\hline 103 & bicyclo[4.1.0]heptane, 3-methyl-7-pentyl- & & 0.41 & 0.09 \\
\hline 5 & butane, 2-methyl- & $78-78-4$ & 7.9 & 0.8 \\
\hline 57 & butane, 1,1'-oxybis- & $142-96-1$ & 0.17 & 0.15 \\
\hline 178 & c15-alkane & & 0.14 & 0.16 \\
\hline 179 & c15-alkane & & 0.16 & 0.15 \\
\hline 95 & c5-cyclohexane & & 0.69 & 0.14 \\
\hline 13 & cyclobutane, methyl- & $598-61-8$ & 0.92 & 0.80 \\
\hline 122 & cyclododecane & $294-62-2$ & 1.4 & 0.3 \\
\hline 85 & cyclohexaen, cyclopropyl- & $32669-86-6$ & 0.19 & 0.17 \\
\hline 30 & cyclohexane, methyl- & $108-87-2$ & 1.13 & 0.06 \\
\hline 40 & cyclohexane, 1,3-dimethyl-, cis- & $638-04-0$ & 0.11 & 0.20 \\
\hline 48 & cyclohexane, ethyl- & $1678-91-7$ & 0.46 & 0.11 \\
\hline 49 & cyclohexane, 1,1,3-trimethyl- & $3073-66-3$ & 0.82 & 0.19 \\
\hline
\end{tabular}




\begin{tabular}{|c|c|c|c|c|}
\hline$\underset{\#}{\text { Cmpd }}$ & Compound & $\begin{array}{c}\mathrm{CAS}^{1} \\
\text { Number }\end{array}$ & $\begin{array}{l}\text { Average }^{2} \\
\left(\mathrm{mg} / \mathrm{m}^{3}\right)\end{array}$ & $\begin{array}{c}\text { Standard } \\
\text { Deviation } \\
\left(\mathrm{mg} / \mathrm{m}^{3}\right)\end{array}$ \\
\hline 61 & cyclohexane, 1-ethyl-4-methyl-, trans- & $6236-88-0$ & 0.057 & 0.099 \\
\hline 68 & cyclohexane, 1,1,4,4-tetramethyl- & & 0.41 & 0.12 \\
\hline 72 & cyclohexane, 1-methyl-4-(1-methylethyl) \& others & & 0.099 & 0.170 \\
\hline 78 & cyclohexane, 1,5-diethyl-2,3-dimethyl- & $74663-66-4$ & 0.52 & 0.25 \\
\hline 83 & cyciohexane, butyl- & $1678-93-9$ & 1.46 & 0.39 \\
\hline 84 & cyciohexane, 1-ethyl-4-methyl, cis- & $4926-78-7$ & 0.16 & 0.14 \\
\hline 92 & cyclohexane, 1,2-diethyl-3-methyl- & $61141-80-8$ & 0.47 & 0.12 \\
\hline 98 & cyclohexane, 1-ethyl-2-propyl- & $62238-33-9$ & 0.28 & 0.26 \\
\hline 125 & cyclohexane, 1-methyl-2-pentyl- & $54411-01-7$ & 0.53 & 0.11 \\
\hline 133 & cyclohexane, 2-butyl-1,1,3-trimethyl- & $54676-39-0$ & 3.0 & 0.6 \\
\hline 137 & cyclohexane, (4-methylpentyl)- & $61142-20-9$ & 2.7 & 0.5 \\
\hline 144 & cyclohexane, 2,4-diethyl-1-methyl- & $61142-70-9$ & 0.15 & 0.14 \\
\hline 147 & cyclohexane, 1,2-diethyl-1-methyl- & $61141-79-5$ & 0.24 & 0.25 \\
\hline 156 & cyclohexane, 1-(cyclohexylmethyl)-2-ethyl- & $54934-93-9$ & 0.31 & 0.10 \\
\hline 165 & cyclohexane, 1-(cyclohexylmethyl)-2-ethyl- & $54934-93-9$ & 0.70 & 0.20 \\
\hline 169 & cyclohexane, (2,2-dimethyicyclopentyl)- & $61142-23-2$ & 0.027 & 0.047 \\
\hline 170 & cyclohexane, 1-(cyclohexylmethyl)-2-methyl- & $54823-94-8$ & 0.25 & 0.07 \\
\hline 94 & cyclohexane, 1-(cyclohexylmethyl)-4-methyl- & $66826-95-7$ & 0.80 & 0.19 \\
\hline 75 & cyclohexane, 1-methyl-4-(1-methylethyi)cis & $6069-98-3$ & 0.23 & 0.22 \\
\hline 21 & cyclopentane, methyl & $96-37-7$ & 2.1 & $0: 3$ \\
\hline 27 & cyclopentane, 1,2-dimethyl-, trans- & $822-50-4$ & 0.324 & 0.305 \\
\hline 41 & cyclopentane, 1,1,3-trimethyl- & $4516-69-2$ & 0.24 & 0.21 \\
\hline 76 & cyclopentane, 1-methyl-3-(2-methylpropyl) & 29053-04-1 & 0.57 & 0.16 \\
\hline 111 & cyclopentane, (2-methylbutyl)- & $53366-38-4$ & 0.35 & 0.10 \\
\hline 132 & cyclopentane, 1-pentyl-2-propyl & $62199-51-3$ & 0.26 & 0.05 \\
\hline 155 & cyclopentane, 1-hexyl-3-methyl & $61142-68-5$ & 0.093 & 0.087 \\
\hline 74 & cyclopentane,2-isopropyl-1,3-dimethyl- & $32281-85-9$ & 0.25 & 0.44 \\
\hline 73 & cyclopentanone,2-methyl-4-(2-methylpropyl) & $69770-96-3$ & 0.16 & 0.27 \\
\hline
\end{tabular}




\begin{tabular}{|c|c|c|c|c|}
\hline Cmpd & Compound & $\begin{array}{c}\mathrm{CAS}^{1} \\
\text { Number }\end{array}$ & $\begin{array}{c}\text { Average } 2 \\
\left(\mathrm{mg} / \mathrm{m}^{3}\right)\end{array}$ & $\begin{array}{c}\text { Standard } \\
\text { Deviation } \\
\left(\mathrm{mg} / \mathrm{m}^{3}\right)\end{array}$ \\
\hline 7 & cyclopropane, ethyl- & $1191-96-4$ & 7.3 & 0.8 \\
\hline 28 & cyclopropane, butyl- & $930-57-4$ & 2.5 & 0.3 \\
\hline 77 & cyclotetrasiloxane, octamethyl- & $556-67-2$ & 1.1 & 0.9 \\
\hline 87 & decane, 5-methyl- & $13151-35-4$ & 0.73 & 0.20 \\
\hline 88 & decane, 4-methyl- & $2847 .-72-5$ & 0.78 & 0.21 \\
\hline 89 & decane, 2-methyl- & $6975-98-0$ & 1.8 & 0.5 \\
\hline 91 & decane, 3-methyl- & $13151-34-3$ & 1.1 & 0.2 \\
\hline 121 & decane, 2,3,6- trimethyi- & $62238-12-4$ & 0.71 & 0.18 \\
\hline 164 & decane, 2,3,5,8-tetramethyl- & & 0.052 & 0.091 \\
\hline 180 & decane, 1,$\}^{\prime}$-oxybiș- & $.2456-28-2$ & 0.65 & 0.63 \\
\hline 108 & dimethyi-decahydronaphthalene & & 0.25 & 0.24 \\
\hline 131 & dimethyl-decahydronaphthalene & & 1.0 & 0.2 \\
\hline 138 & dodecane, 6-methyl- & $6044-71-9$ & 0.80 & 0.15 \\
\hline 139 & dodecane, 5-methyl- & $17453-93-9$ & 0.57 & 0.12 \\
\hline 140 & dodecane, 4-methyl- & $6117-97-1$ & 1.8 & 0.4 \\
\hline 143 & dodecane, 4,6-dimethyl- & $61141-72-8$ & 6.4 & 6.1 \\
\hline 154 & dodecane, 2,5-dimethyl- & $56292-65-0$ & 2.5 & 0.7 \\
\hline 167 & dodecane, 3-methyl- & $17312-57-1$ & 0.87 & 0.75 \\
\hline 168 & dodecane, 2,6,10-trimethyl- & $3891-98-3$ & 7.3 & 2.1 \\
\hline 182 & dodecane, 2-methyl-8-propyl- & $55045-07-3$ & 2.9 & 0.8 \\
\hline 189 & dodecanoic acid & $143-07-7$ & 0.31 & 0.10 \\
\hline 204 & ethanol, 2-(tetradecyloxy)- & $2136-70-1$ & $0.70^{\circ}$ & 1.22 \\
\hline 93 & formic acid, 2,6-dimethyl-5-hepten-2-ol ester & & 0.37 & 0.10 \\
\hline 9 & furan & $110-00-9$ & 0.55 & 0.96 \\
\hline 22 & furan, tetrahydro- & $109-99-9$ & 8.5 & 2.0 \\
\hline 177 & heptadecane, 7-methyl- & $20959-33-5$ & 0.17 & 0.29 \\
\hline 35 & heptane, 2,3,5-trimethyl- & $20278-85-7$ & 0.65 & 1.12 \\
\hline 36 & heptane, 2,3,6-trimethyl- & $4032-93-3$ & 1.26 & 1.10 \\
\hline
\end{tabular}




\begin{tabular}{|c|c|c|c|c|}
\hline$\underset{\#}{\text { Cmpd }}$ & Compound & $\begin{array}{c}\text { CAS }^{1} \\
\text { Number }\end{array}$ & $\begin{array}{l}\text { Average }^{2} \\
\left(\mathrm{mg} / \mathrm{m}^{3}\right)\end{array}$ & $\begin{array}{c}\text { Standard } \\
\text { Deviation } \\
\left(\mathrm{mg} / \mathrm{m}^{3}\right)\end{array}$ \\
\hline 38 & heptane, 3-methyl- & $589-81-1$ & 0.19 & 0.32 \\
\hline 47 & heptane, 2,6-dimethyl- & $1072-05-5$ & 0.56 & 0.07 \\
\hline 51 & heptane, 2,3-dimethyl- & $3074-71-3$ & 0.09 & 0.16 \\
\hline 55 & heptane, 3,5-dimethyl- & $926-82-9$ & 0.073 & 0.126 \\
\hline 63 & heptane, 4-(1-methylethyl)- & $52896-87-4$ & 0.15 & 0.26 \\
\hline 193 & hexacosane & $630-01-3$ & 0.099 & 0.172 \\
\hline 185 & hexadecane, 2,6,10,14-tetramethyl- & $638-36-8$ & 0.091 & 0.080 \\
\hline 190 & hexadecane & $544-76-3$ & 0.053 & 0.092 \\
\hline 201 & hexadecanoic acid & $57-10-3$ & 1.4 & 1.4 \\
\hline 203 & hexadecanoic acid, 1-methylethyl ester & $142-91-6$ & 0.44 & 0.31 \\
\hline 46 & hexamethylcyclotrisiloxane & $541-05-9$ & 0.13 & 0.22 \\
\hline 42 & hexanal, 3-methyl- & $19269-28-4$ & 0.24 & 0.42 \\
\hline 26 & hexane, 2-methyl- & $591-76-4$ & 1.34 & 0.05 \\
\hline 6 & methane, trichlorofluro- & $75-69-4$ & 11.9 & 13.0 \\
\hline 31 & mixture & & 0.14 & 0.24 \\
\hline 60 & mixture & & 0.069 & 0.119 \\
\hline 142 & mixture & & 0.45 & 0.10 \\
\hline 90 & naphthalene, decahydro-, trans- & $493-02-7$ & 1.1 & 0.3 \\
\hline 105 & naphthalene, decahydro-2-methyl- & $2958-76-1$ & 2.2 & 0.6 \\
\hline 112 & naphthalene, decahydro-2-methyl- & $2958-76-1$ & 5.9 & 1.6 \\
\hline 114 & naphthalene, decahydro-2-methyl- & $2958-76-1$ & 0.21 & 0.19 \\
\hline 123 & naphthalene, decahydro-2,6-dimethyl- & $1618-22-0$ & 1.4 & 0.3 \\
\hline 124 & naphthalene, decahydro-2,3-dimethyl- & $1008-80-6$ & 0.11 & 0.11 \\
\hline 135 & naphthalene, decahydro-1,6-dimethyi- & $1750-51-2$ & 0.36 & 0.08 \\
\hline 158 & naphthalene, 2-butyldecahydro- & $6305-52-8$ & 0.32 & 0.09 \\
\hline 67 & nonane, 4-methyl- & $17301-94-9$ & 0.57 & 0.25 \\
\hline 79 & nonane, 2,6-dimethyl- & $17302-28-2$ & 2.2 & 1.1 \\
\hline 101 & nonane, 3,7-dimethyl- & $17302-32-8$ & 0.80 & 1.39 \\
\hline
\end{tabular}




\begin{tabular}{|c|c|c|c|c|}
\hline$\underset{\#}{C \text { Cmpd }}$ & Compound & $\begin{array}{c}\mathrm{CAS}^{1} \\
\text { Number }\end{array}$ & $\begin{array}{c}\text { Average }^{2} \\
\left(\mathrm{mg} / \mathrm{m}^{3}\right)\end{array}$ & $\begin{array}{c}\text { Standard } \\
\text { Deviation } \\
\left(\mathrm{mg} / \mathrm{m}^{3}\right)\end{array}$ \\
\hline 208 & octadecane & $593-45-3$ & 0.025 & 0.043 \\
\hline 56 & octane, 3-methyl and c2-benzene & & 0.43 & 0.74 \\
\hline 80 & octane, 6-ethyl-2-methyl- & $62016-19-7$ & 0.19 & 0.20 \\
\hline 160 & octane, 2-cyclohexyl- & $2883-05-8$ & 2.6 & 0.8 \\
\hline 10 & oxirane, ethenyi- & $930-22-3$ & 0.8 & 1.4 \\
\hline 174 & pentadecane & $629-62-9$ & 1.2 & 1.7 \\
\hline 175 & pentadecane & $629-62-9$ & 0.32 & 0.55 \\
\hline 183 & pentadecane, 2-methyl- & $1560-93-6$ & 0.18 & 0.17 \\
\hline 188 & pentadecane & $629-62-9$ & 1.6 & 0.5 \\
\hline 195 & pentadecanoic acid & $1002-84-2$ & 0.36 & 0.14 \\
\hline 15 & pentane, 2-methyl- & $107-83-5$ & 15.1 & 0.9 \\
\hline 17 & pentane, 3-methyl- & $96-14-0$ & 2.5 & 0.2 \\
\hline 202 & phthalate & & 0.081 & 0.140 \\
\hline 32 & propane, 2-nitro- $\&$ others & & 0.14 & 0.23 \\
\hline 152 & tetradecane & $629-59-4$ & 0.22 & 0.38 \\
\hline 159 & tetradecane & $629-59-4$ & 1.0 & 0.3 \\
\hline 171 & tetradecane & $629-59-4$ & 7.3 & 2.0 \\
\hline 184 & tetradecane, 3-methyl- & $18435-22-8$ & 0.13 & 0.22 \\
\hline 192 & tetradecanoic acid & $544-63-8$ & 2.1 & 1.7 \\
\hline 145 & tridecane, 7-methyl- & $26730-14-3$ & 3.9 & 6.8 \\
\hline 150 & tridecane, 5-methyl- & $25117-31-1$ & 0.32 & 0.31 \\
\hline 161 & tridecane, 4-methyl- & $26730-12-1$ & 1.5 & 0.4 \\
\hline 162 & tridecane, 2-methyl- & $1560-96-9$ & 2.0 & 0.6 \\
\hline 166 & tridecane, 3-methyl- & $6418-41-3$ & 0.25 & 0.44 \\
\hline 172 & tridecane, 4,8-dimethyl- & $55030-62-1$ & 1.5 & 1.4 \\
\hline 173 & tridecane, 3-ethyl- & $13286-73-2$ & 0.089 & 0.154 \\
\hline 102 & undecane, 5-methyl- & $1632-70-8$ & 2.9 & 0.8 \\
\hline 104 & undecane, 4-methyl- & $2980-69-0$ & 0.36 & 0.09 \\
\hline
\end{tabular}


WHC-SD-WM-ER-422 REV. 2

\begin{tabular}{clccc}
\hline $\begin{array}{c}\text { Cmpd } \\
\#\end{array}$ & Compound & $\begin{array}{c}\text { CAS } \\
\text { Number }\end{array}$ & $\begin{array}{c}\text { Average } \\
\left(\mathrm{mg} / \mathrm{m}^{3}\right)\end{array}$ & $\begin{array}{c}\text { Standard } \\
\text { Deviation } \\
\left(\mathrm{mg} / \mathrm{m}^{3}\right)\end{array}$ \\
\hline 106 & undecane, 3,8-dimethyl- & $17301-30-3$ & 1.0 & 0.9 \\
107 & undecane, 4,7-dimethyl- & $17301-32-5$ & 0.77 & 1.34 \\
116. & undecane, 4-methyl- & $2980-69-0$ & 1.9 & 0.5 \\
117 & undecane, 2-methyl- & $7045-71-8$ & 3.8 & 1.0 \\
118 & undecane, 2,3-dimethyl- & $17312-77-5$ & 0.97 & 0.28 \\
119 & undecane, 3-methyl- & $1002-43-3$ & 2.1 & 0.6 \\
127 & undecane, 2,4-dimethyl- & $17312-80-0$ & 0.16 & 0.15 \\
128 & undecane, 2,6-dimethyl- & $17301-23-4$ & 7.5 & 1.7 \\
129 & undecane, 2,7-dimethyl- & $17301-24-5$ & 0.40 & 0.37 \\
130 & undecane, 3,7-dimethyl- & $17301-29-0$ & 0.24 & 0.42 \\
141 & undecane, 2,10-dimethyl- & $17301-27-8$ & 3.3 & 0.7 \\
151 & undecane, 4,6-dimethyl- & $17312-82-2$ & 0.47 & 0.44 \\
153 & undecane, 6,6-dimethyl- & $17312-76-4$ & 0.30 & 0.51 \\
163 & undecane, 4,6-dimethyl- & $17312-82-2$ & 0.037 & 0.064 \\
\hline \hline Sum of tentatively identified compounds: & & 251.9 & \\
\hline \hline
\end{tabular}

$1 \mathrm{CAS}=$ Chemical Abstract Service.

2 Average of 3,55 $\mathrm{ml}$ TST samples, values listed are estimates. 
WHC-SD-WM-ER-422 REV. 2 .

Table 4-9

Tank BY-108 Tentatively Identified Organic Compounds in TST Samples Sorted by Estimated Concentration -Analyses by Oak Ridge National Laboratory

\begin{tabular}{|c|c|c|c|c|}
\hline $\begin{array}{c}\text { Cmpd } \\
\#\end{array}$ & Compound & $\begin{array}{c}\mathrm{CAS}^{1} \\
\text { Number }\end{array}$ & $\begin{array}{c}\text { Average }^{2} \\
\left(\mathrm{mg} / \mathrm{m}^{3}\right)\end{array}$ & $\begin{array}{c}\text { Standard } \\
\text { Deviation } \\
\left(\mathrm{mg} / \mathrm{m}^{3}\right)\end{array}$ \\
\hline 15 & pentane, 2-methyl- & $107-83-5$ & 15.1 & 0.9 \\
\hline 6 & methane, trichlorofluro- & $75-69-4$ & 11.9 & 13.0 \\
\hline 22 & furan, tetrahydro- & $109-99-9$ & 8.5 & 2.0 \\
\hline 5 & butane, 2-methyl- & $78-78-4$ & 7.9 & 0.8 \\
\hline 128 & undecane, 2,6-dimethyl- & $17301-23-4$ & 7.5 & 1.7 \\
\hline 168 & dodecane, 2,6,10-trimethyl- & $3891-98-3$ & 7.3 & 2.1 \\
\hline 7 & cyclopropane, ethyl- & $1191-96-4$ & 7.3 & 0.8 \\
\hline 171 & tetradecane & $.629-59-4$ & 7.3 & 2.0 \\
\hline 143 & dodecane, 4,6-dimethyl- & $61141-72-8$ & 6.4 & 6.1 \\
\hline 8 & 3-buten-1-ol & $627-27-0$ & 6.1 & 10.5 \\
\hline 112 & naphthalene, decahydro-2-methyl- & $2958-76-1$ & 5.9 & 1.6 \\
\hline 11 & 2-propanol & $67-63-0$ & 5.3 & 1.6 \\
\hline 70 & 3-buten-2-ol & $598-32-3$ & 4.8 & 3.9 \\
\hline 145 & tridecane, 7-methyl- & $26730-14-3$ & 3.9 & 6.8 \\
\hline 117 & undecane, 2-methyl- & $7045-71-8$ & 3.8 & 1.0 \\
\hline 115 & 6-methyiundecane & $17302-33-9$ & 3.4 & 0.9 \\
\hline 141 & undecane, 2,10-dimethyl- & $17301-27-8$ & 3.3 & 0.7 \\
\hline 19 & 1-hexene & $592-41-6$ & 3.0 & 2.6 \\
\hline 182 & dodecane, 2-methyl-8-propyl- & $55045-07-3$ & 2.9 & 0.8 \\
\hline 102 & undecane, 5-methyl- & $1632-70-8$ & 2.9 & 0.8 \\
\hline 137 & cyclohexane, (4-methyipentyi). & $61142-20-9$ & 2.7 & 0.5 \\
\hline 18 & 1-pentene, 2-methyl- & $763-29-1$ & 2.6 & 1.6 \\
\hline 160 & octane, 2-cyclohexyl- & $2883-05-8$ & 2.6 & 0.8 \\
\hline 17 & pentane, 3-methyl- & $96-14-0$ & 2.5 & 0.2 \\
\hline 154 & dodecane, 2,5-dimethyl- & $56292-65-0$ & $2.5^{\circ}$ & 0.7 \\
\hline 14 & 1-pentene, 4-methyl- & $691-37-2$ & 2.5 & 0.3 \\
\hline
\end{tabular}


WHC-SD-WM-ER-422 REV. 2

\begin{tabular}{|c|c|c|c|c|}
\hline $\begin{array}{c}\text { Cmpd } \\
\#\end{array}$ & Compound & $\begin{array}{c}\mathrm{CAS}^{1} \\
\text { Number }\end{array}$ & $\begin{array}{c}\text { Average } \\
\left(\mathrm{mg} / \mathrm{m}^{3}\right)\end{array}$ & $\begin{array}{c}\text { Standard } \\
\text { Deviation } \\
\left(\mathrm{mg} / \mathrm{m}^{3}\right)\end{array}$ \\
\hline 28 & cyclopropane, butyl- & $930-57-4$ & 2.5 & 0.3 \\
\hline 148 & 6-tridecene, 7-methyl- & $24949-42-6$ & 2.3 & 0.7 \\
\hline 79 & nonane, 2,6-dimethyl- & $17302-28-2$ & 2.2 & 1.1 \\
\hline 199 & alkane & & 2.2 & 3.6 \\
\hline 105 & naphthalene, decahydro-2-methyl- & 2958-76-1 & 2.2 & 0.6 \\
\hline 192 & tetradecanoic acid & $544-63-8$ & 2.1 & 1.7 \\
\hline 119 & undecane, 3-methyl- & $1002-43-3$ & 2.1 & 0.6 \\
\hline 21 & cyclopentane, methyl- & $96-37-7$ & 2.1 & 0.3 \\
\hline 2 & 1-propene, 2-methyl- & $115-11-7$ & 2.1 & 0.4 \\
\hline 162 & tridecane, 2-methyl- & $1560-96-9$ & 2.0 & 0.6 \\
\hline 116 & undecane, 4-methyl- & $2980-69-0$ & 1.9 & 0.5 \\
\hline 89 & decane, 2-methyl- & $6975-98-0$ & 1.8 & 0.5 \\
\hline 140 & dodecane, 4-methyl- & $6117-97-1$ & 1.8 & 0.4 \\
\hline 1 & 1-propene, 2-methyl- & $115-11-7$ & 1.6 & 1.5 \\
\hline 188 & pentadecane & $629-62-9$ & 1.6 & 0.5 \\
\hline 161 & tridecane, 4-methyi- & $26730-12-1$ & 1.5 & 0.4 \\
\hline 172 & tridecane, 4,8-dimethyl- & $55030-62-1$ & 1.5 & 1.4 \\
\hline 194 & benzenesulfonamide, $\mathrm{N}$-butyl- & $3622-84-2$ & $1: 5$ & 0.7 \\
\hline 83 & cyclohexane, butyl- & $1678-93-9$ & 1.46 & 0.39 \\
\hline 122 & cyclododecane & $294-62-2$ & 1.4 & 0.3 \\
\hline 66 & 2-heptanone, 6-methyl- & $928-68-7$ & 1.4 & 0.6 \\
\hline 201 & hexadecanoic acid & $57-10-3$ & 1.4 & 1.4 \\
\hline 123 & naphthalene, decahydro-2,6-dimethyl- & $1618-22-0$ & 1.4 & 0.3 \\
\hline 26 & hexane, 2-methyl- & $591-76-4$ & 1.34 & 0.05 \\
\hline 36 & heptane, 2,3,6-trimethyl- & $4032-93-3$ & 1.26 & 1.10 \\
\hline 174 & pentadecane & $629-62-9$ & 1.2 & 1.7 \\
\hline 30 & cyciohexane, methyi- & $108-87-2$ & 1.13 & 0.06 \\
\hline 77 & cyclotetrasiloxane, octamethyl- & $556-67-2$ & 1.1 & 0.9 \\
\hline
\end{tabular}




\begin{tabular}{|c|c|c|c|c|}
\hline $\begin{array}{c}\text { Cmpd } \\
\#\end{array}$ & Compound & $\begin{array}{c}\mathrm{CAS}^{\dagger} \\
\text { Number }\end{array}$ & $\begin{array}{c}\text { Average }^{2} \\
\left(\mathrm{mg} / \mathrm{m}^{3}\right)\end{array}$ & $\begin{array}{l}\text { Standard } \\
\text { Deviation } \\
\left(\mathrm{mg} / \mathrm{m}^{3}\right)\end{array}$ \\
\hline 90 & naphthalene, decahydro-, trans- & $493-02-7$ & 1.1 & 0.3 \\
\hline 91 & decane, 3-methyl- & $13151-34-3$ & 1.1 & 0.2 \\
\hline 131 & dimethyl-decahydronaphthalene & & 1.0 & 0.2 \\
\hline 106 & undecane, 3,8-dimethyl- & $17301-30-3$ & 1.0 & 0.9 \\
\hline 96 & 5-undecene & $4941-53-1$ & 1.0 & 0.3 \\
\hline 159 & tetradecane & $629-59-4$ & 1.0 & 0.3 \\
\hline 118 & undecane, 2,3-dimethyl- & $17312-77-5$ & 0.97 & 0.28 \\
\hline 97 & 2-nonanone and others . & & 0.93 & 0.23 \\
\hline 13 & cyclobutane, methyl- & $598-61-8$ & 0.92 & 0.80 \\
\hline 12 & 2-pentene, (Z)- & $627-20-3$ & 0.88 & 0.76 \\
\hline 167 & dodecane, 3-methyl- & $17312-57-1$ & 0.87 & 0.75 \\
\hline 120 & 4-undecene, 4-methyl- & $61142-40-3$ & 0.86 & 0.18 \\
\hline 49 & cyclohexane, 1,1,3-trimethyl- & $3073-66-3$ & 0.82 & 0.19 \\
\hline 44 & 2H-pyran-2-one, tetrahydro-5,6-dimethyl- & $24405-16-1$ & 0.81 & 0.72 \\
\hline 101 & nonane, 3,7-dimethyl- & $17302-32-8$ & 0.80 & 1.39 \\
\hline 10 & oxirane, ethenyl- & $930-22-3$ & 0.8 & 1.4 \\
\hline 138 & dodecane, 6-methyl- & $6044-71-9$ & 0.80 & 0.15 \\
\hline 88 & decane, 4-methyl- & $2847-72-5$ & 0.78 & 0.21 \\
\hline 107 & undecane, 4,7-dimethyl- & $17301-32-5$ & 0.77 & 1.34 \\
\hline 56 & octane, 3-methyl and c2-benzene & & 0.43 & 0.74 \\
\hline 37 & 1-octene & $111-66-0$ & 0.74 & 0.65 \\
\hline 146 & $\begin{array}{l}2(3 \mathrm{H}) \text {-benzofuranone, } 3 a, 4,5,6 \text { tetrahydro-3a; } \\
6,6 \text {-trimethyl- }\end{array}$ & $16778-26-0$ & 0.73 & 0.20 \\
\hline 87 & decane, 5-methyl- & $13151-35-4$ & 0.73 & 0.20 \\
\hline 121 & decane, 2,3,6-trimethyl- & $62238-12-4$ & 0.71 & 0.18 \\
\hline 204 & ethanol, 2-(tetradecyloxy)- & $2136-70-1$ & 0.70 & 1.22 \\
\hline 95 & c5-cyclohexane & & 0.69 & 0.14 \\
\hline 58 & 3-heptanone & $106-35-4$ & 0.68 & 0.10 \\
\hline 20 & 2-butanone & $78-93-3$ & 0.66 & 1.14 \\
\hline
\end{tabular}




\begin{tabular}{|c|c|c|c|c|}
\hline Cmpd & Compound & $\begin{array}{c}\mathrm{CAS}^{\dagger} \\
\text { Number }\end{array}$ & $\begin{array}{l}\text { Average }^{2} \\
\left(\mathrm{mg} / \mathrm{m}^{3}\right)\end{array}$ & $\begin{array}{c}\text { Standard } \\
\text { Deviation } \\
\left(\mathrm{mg} / \mathrm{m}^{3}\right)\end{array}$ \\
\hline 35 & heptane, 2,3,5-trimethyl- & 20278-85-7 & 0.65 & 1.12 \\
\hline 180 & decane, 1,1'-oxybis- & $2456-28-2$ & 0.65 & 0.63 \\
\hline 149 & 5-tetradecene, $(\mathrm{E})$ - & $41446-66-6$ & 0.63 & 0.17 \\
\hline 133 & cyclohexane, 2-butyl-1,1,3-trimethyl- & $54676-39-0$ & 3.0 & 0.6 \\
\hline 24 & 1-pentene, 3,4-dimethyl- & $7385-78-6$ & 0.59 & 1.02 \\
\hline 67 & nonane, 4-methyl- & $17301-94-9$ & 0.57 & 0.25 \\
\hline 76 & cyclopentane, 1-methyl-3-(2-methylpropyl) & 29053-04-1 & 0.57 & 0.16 \\
\hline 139 & dodecane, 5-methyl- & $17453-93-9$ & 0.57 & 0.12 \\
\hline 157 & 4-nonene, 2,3,3-trimethyl-, (E)- & $63830-68-2$ & 0.57 & 0.16 \\
\hline 47 & heptane, 2,6-dimethyl- & $1072-05-5$ & 0.56 & 0.07 \\
\hline 9 & furan & $110-00-9$ & 0.55 & 0.96 \\
\hline 125 & cyclohexane, 1-methyl-2-pentyl- & $54411-01-7$ & 0.53 & 0.11 \\
\hline 25 & 1-hexene, 5-methyl- & $3524-73-0$ & 0.53 & 0.91 \\
\hline 198 & alkane & & 0.53 & 0.92 \\
\hline 34 & 1-heptene, 3-methyl- & $4810-09-7$ & 0.52 & 0.46 \\
\hline 78 & cyclohexane, 1,5-diethyl-2,3-dimethyl- & $74663-66-4$ & 0.52 & 0.25 \\
\hline 4 & 1-butene, 3-methyl- & $563-45-1$ & 0.51 & 0.88 \\
\hline 100 & 1-undecene, 4-methyl- & $74630-39-0$ & 0.51 & 0.89 \\
\hline 82 & 3-decyne & $2384-85-2$ & 0.51 & 0.17 \\
\hline 99 & 5-undecene & $4941-53-1$ & 0.49 & 0.13 \\
\hline 23 & 1,3-pentadiene, 2-methyl- & $1118-58-7$ & 0.49 & 0.85 \\
\hline 62 & 3,4-nonadiene & $37050-03-6$ & 0.48 & 0.14 \\
\hline 3 & 1-propene, 2-methyl- & $115-11-7$ & 0.48 & 0.84 \\
\hline 151 & undecane, 4,6-dimethyl- & $17312-82-2$ & 0.47 & 0.44 \\
\hline 16 & 1-propene, 2-1ีuoro- & $1184-60-7$ & 0.47 & 0.82 \\
\hline 48 & cyclohexane, ethyl- & $1678-91-7$ & 0.46 & $0.11^{\circ}$ \\
\hline 176 & alkyl-cyclohexane & & 0.45 & 0.15 \\
\hline 181 & 1-octadecanol & $112-92-5$ & 0.45 & 0.78 \\
\hline
\end{tabular}




\begin{tabular}{|c|c|c|c|c|}
\hline$\underset{\#}{\text { Cmpd }}$ & Compound & $\begin{array}{c}\mathrm{CAS}^{1} \\
\text { Number }\end{array}$ & $\begin{array}{l}\text { Average }^{2} \\
\left(\mathrm{mg} / \mathrm{m}^{3}\right)\end{array}$ & $\begin{array}{c}\text { Standard } \\
\text { Deviation } \\
\left(\mathrm{mg} / \mathrm{m}^{3}\right)\end{array}$ \\
\hline 142 & mixture & & 0.45 & 0.10 \\
\hline 203 & hexadecanoic acid, 1-methylethyl ester & $142-91-6$ & 0.44 & 0.31 \\
\hline 126 & 5-heptenal, 2,6-dimethyl- & $106-72-9$ & 0.42 & 0.11 \\
\hline 53 & benzene, 1,2-dimethyl- & $95-47-6$ & 0.40 & 0.69 \\
\hline 69 & 2-octanol & $123-96-6$ & 0.40 & 0.20 \\
\hline 129 & undecane, 2,7-dimethyl- & $17301-24-5$ & 0.40 & 0.37 \\
\hline 109 & 2-undecene, 8-methyl- & $74630-44-7$ & 0.38 & 0.12 \\
\hline 59 & benzene, 1,2-dimethyl- & $95-47-6$ & 0.38 & .0 .06 \\
\hline 110 & 1-dodecene & $112-41-4$ & 0.38 & 0.08 \\
\hline 135 & naphthalene, decahydro-1,6-dimethyl- & $1750-51-2$ & 0.36 & 0.08 \\
\hline 195 & pentadecanoic acid & $1002-84-2$ & 0.36 & 0.14 \\
\hline 104 & undecane, 4-methyl- & $2980-69-0$ & 0.36 & 0.09 \\
\hline 54 & benzene, 1,4-dimethyl- & $106-42-3$ & 0.35 & 0.61 \\
\hline 111 & cyclopentane, (2-methylbutyi)- & $53366-38-4$ & 0.35 & 0.10 \\
\hline 134 & 1-octanol, 2-butyl-. & $3913-02-8$ & 0.35 & 0.08 \\
\hline 27 & cyclopentane, 1,2-dimethyl-, trans- & $822-50-4$ & 0.324 & 0.305 \\
\hline 150 & tridecane, 5-methyl- & $25117-31-1$ & 0.32 & 0.31 \\
\hline 200 & 9-hexadecenoic acid & $2091-29-4$ & 0.32 & 0.31 \\
\hline 158 & naphthalene, 2-butyidecahydro- & $6305-52-8$ & 0.32 & 0.09 \\
\hline 175 & pentadecane & $629-62-9$ & 0.32 & 0.55 \\
\hline 50 & 1-nonene & $124-11-8$ & 0.31 & 0.27 \\
\hline 189 & dodecanoic acid & $143-07-7$ & 0.31 & 0.10 \\
\hline 156 & cyclohexane, 1-(cyclohexylmethyl)-2-ethyl- & $54934-93-9$ & 0.31 & 0.10 \\
\hline 153 & undecane, 6,6-dimethyl- & $17312-76-4$ & 0.30 & 0.51 \\
\hline 98 & cyclohexane, 1-ethyl-2-propyl- & $62238-33-9$ & 0.28 & 0.26 \\
\hline 132 & cyclopentane, 1-pentyl-2-propyl- & $62199-51-3$ & 0.26 & 0.05 \\
\hline 74 & cyclopentane,2-isopropyl-1,3-dimethyl- & $32281-85-9$ & 0.25 & 0.44 \\
\hline 108 & dimethyl-decahydronaphthalene & & 0.25 & 0.24 \\
\hline
\end{tabular}




\begin{tabular}{|c|c|c|c|c|}
\hline$\underset{\#}{\text { Cmpd }}$ & Compound & $\begin{array}{c}\text { CAS }^{1} \\
\text { Number }\end{array}$ & $\begin{array}{l}\text { Average }{ }^{2} \\
\left(\mathrm{mg} / \mathrm{m}^{3}\right)\end{array}$ & $\begin{array}{c}\text { Standard } \\
\text { Deviation } \\
\left(\mathrm{mg} / \mathrm{m}^{3}\right)\end{array}$ \\
\hline 170 & cyclohexane, 1-(cyclohexylmethyl)-2-methyl- & $54823-94-8$ & 0.25 & 0.07 \\
\hline 33 & 1-heptene, 6-methyl- & $5026-76-6$ & 0.25 & 0.43 \\
\hline 207 & 1-hexadecene & $629-73-2$ & 0.25 & 0.43 \\
\hline 166 & tridecane, 3-methyl- & $6418-41-3$ & 0.25 & 0.44 \\
\hline 130 & undecane, 3,7-dimethyl- & $17301-29-0$ & 0.24 & 0.42 \\
\hline 42 & hexanal, 3-methyl- & $19269-28-4$ & 0.24 & 0.42 \\
\hline 41 & cyclopentane, 1,1,3-trimethyl- & $4516-69-2$ & 0.24 & 0.21 \\
\hline 147 & cyclohexane, 1,2-diethyl-1-methyl- & $61141-79-5$ & 0.24 & 0.25 \\
\hline 191 & benzenamine, $\mathrm{N}$-phenyl- & $122-39-4$ & 0.23 & 0.06 \\
\hline 75 & cyclohexane, 1-methyl-4-(1-methylethyi)cis & $6069-98-3$ & 0.23 & 0.22 \\
\hline 206 & 5-eicosane, $(E)$ & $74685-30-6$ & 0.23 & 0.39 \\
\hline 71 & 2-heptyl furan & & 0.22 & 0.23 \\
\hline 186 & 7-hexadecene, (Z)- & $35507-09-6$ & 0.22 & 0.06 \\
\hline 152 & tetradecane & $629-59-4$ & 0.22 & 0.38 \\
\hline 114 & naphthalene, decahydro-2-methyl- & $2958-76-1$ & 0.21 & 0.19 \\
\hline 113 & 3-dodecene, (Z)- & $7239-23-8$ & 0.20 & 0.19 \\
\hline 165 & cyclohexane, 1-(cyclohexyimethyl)-2-ethyl- & $54934-93-9$ & 0.70 & 0.20 \\
\hline 80 & octane, 6-ethyl-2-methyl- & $62016-19-7$ & 0.19 & 0.20 \\
\hline 38 & heptane, 3-methyi- & $589-81-1$ & 0.19 & 0.32 \\
\hline 85 & cyclohexaen, cyclopropyl- & $32669-86-6$ & 0.19 & 0.17 \\
\hline 94 & cyclohexane,1-(cyclohexylmethyl)-4-methyl- & $66826-95-7$ & 0.80 & 0.19 \\
\hline 183 & pentadecane, 2-methyl- & $1560-93-6$ & 0.18 & 0.17 \\
\hline 43 & 1-octene & $111-66-0$ & 0.18 & 0.31 \\
\hline 57 & butane, 1,1'-oxybis- & $142-96-1$ & 0.17 & 0.15 \\
\hline 177 & heptadecane, 7-methyl- & $20959-33-5$ & 0.17 & 0.29 \\
\hline 72 & cyclohexane, 1-methyl-4-(1-methylethyl) \& others & & 0.099 & 0.170 \\
\hline 179 & c15-alkane & & 0.16 & 0.15 \\
\hline 73 & cyclopentanone,2-methyl-4-(2-methylpropyl) & $69770-96-3$ & 0.16 & 0.27 \\
\hline
\end{tabular}




\begin{tabular}{|c|c|c|c|c|}
\hline $\begin{array}{c}\text { Cmpd } \\
\#\end{array}$ & Compound & $\begin{array}{c}\text { CAS }^{1} \\
\text { Number }\end{array}$ & $\begin{array}{c}\text { Average } 2 \\
\left(\mathrm{mg} / \mathrm{m}^{3}\right)\end{array}$ & $\begin{array}{c}\text { Standard } \\
\text { Deviation } \\
\left(\mathrm{mg} / \mathrm{m}^{3}\right)\end{array}$ \\
\hline 127 & undecane, 2,4-dimethyl- & $17312-80-0$ & 0.16 & 0.15 \\
\hline 84 & cyclohexane, 1-ethyl-4-methyl, cis & $4926-78-7$ & 0.16 & 0.14 \\
\hline 29 & 2-heptene & $592-77-8$ & 0.16 & 0.28 \\
\hline 144 & cyclohexane, 2,4-diethyl-1-methyl- & $61142-70 m 9$ & 0.15 & 0.14 \\
\hline 63 & heptane, 4-(1-methylethyl)- & $52896-87-4$ & 0.15 & 0.26 \\
\hline 31 & mixture & & $0.14^{*}$ & 0.24 \\
\hline 178 & c15-alkane & & 0.14 & 0.16 \\
\hline 32 & propane, 2-nitro- \& others & & 0.14 & 0.23 \\
\hline 86 & 1-ethyl-2,2,6-trimethylcyclohexane & & 0.55 & 0.14 \\
\hline 81 & 1,4-pentadiene, 2,3,4-trimethyl- \& others & & 0.079 & 0.137 \\
\hline 184 & tetradecane, 3-methyl- & $18435-22-8$ & 0.13 & 0.22 \\
\hline 65 & 4-nonyne & $20184-91-2$ & 0.13 & 0.23 \\
\hline 46 & hexamethylcyclotrisiloxane & $541-05-9$ & 0.13 & 0.22 \\
\hline 92 & cyclohexane, 1,2-diethyl-3-methyl- & $61141-80-8$ & 0.47 & 0.12 \\
\hline 45 & 1-octanol & $111-87-5$ & 0.12 & 0.20 \\
\hline 68 & cyclohexane, 1,1,4,4-tetramethyl- & & 0.41 & 0.12 \\
\hline 40 & cyclohexane, 1,3-dimethyl-, cis- & $638-04-0$ & 0.11 & 0.20 \\
\hline 124 & naphthalene, decahydro-2,3-dimethyl- & $1008-80-6$ & 0.11 & 0.11 \\
\hline 39 & 3-pentanol, 2-methyl and others & & 0.11 & 0.19 \\
\hline 64 & 1-hexene, 4,5-dimethyl- & $16106-59-5$ & 0.11 & 0.20 \\
\hline 187 & 2-pentanone, 4-cyclohexayliden-3,3-diethyl- & & 0.11 & 0.10 \\
\hline 93 & formic acid, 2,6-dimethyl-5-hepten-2-ol ester & & 0.37 & 0.10 \\
\hline 136 & $(\mathrm{E}, \mathrm{E})(3 \mathrm{~S}, 8 \mathrm{~S}), 3,8$-dimethyldeca-4,6-diene & & 0.47 & 0.10 \\
\hline 193 & hexacosane & $630-01-3$ & 0.099 & 0.172 \\
\hline 196 & 1-hexadecanol & $36653-82-4$ & 0.097 & 0.174 \\
\hline 155 & cyclopentane, 1-hexyl-3-methyl- & $61142-68-5$ & 0.093 & 0.087 \\
\hline 185 & hexadecane, 2,6,10,14-tetramethyl- & $638-36-8$ & 0.091 & 0.080 \\
\hline 51 & heptane, 2,3-dimethyl- & $3074-71-3$ & 0.09 & 0.16 \\
\hline
\end{tabular}


WHC-SD-WM-ER-422 REV. 2

\begin{tabular}{clccc}
\hline \hline $\begin{array}{c}\text { Cmpd } \\
\#\end{array}$ & Compound & $\begin{array}{c}\mathrm{CAS}^{1} \\
\text { Number }\end{array}$ & $\begin{array}{c}\text { Average } \\
\left(\mathrm{mg} / \mathrm{m}^{3}\right)\end{array}$ & $\begin{array}{c}\text { Standard } \\
\text { Deviation } \\
\left(\mathrm{mg} / \mathrm{m}^{3}\right)\end{array}$ \\
\hline \hline 103 & bicyclo[4.1.0]heptane, 3-methyl-7-pentyl- & & 0.41 & 0.09 \\
205 & alkane & & 0.09 & 0.15 \\
173 & tridecane, 3-ethyl- & $13286-73-2$ & 0.089 & 0.154 \\
202 & phthalate & & 0.081 & 0.140 \\
55 & heptane, 3,5-dimethyl- & $926-82-9$ & 0.073 & 0.126 \\
60 & mixture & & 0.069 & 0.119 \\
61 & cyclohexane, 1-ethyl-4-methyl-, trans- & $6236-88-0$ & 0.057 & 0.099 \\
190 & hexadecane & $544-76-3$ & 0.053 & 0.092 \\
164 & decane, 2,3,5,8-tetramethyl- & & 0.052 & 0.091 \\
52 & benzene, ethyl and octane, 2-methyl- & & 0.54 & 0.05 \\
197 & 1-hexadecene & $629-73-2$ & 0.049 & 0.085 \\
163 & undecane, 4,6-dimethyl- & $17312-82-2$ & 0.037 & 0.064 \\
169 & cyclohexane, (2,2-dimethylcyciopentyl)- & $61142-23-2$ & 0.027 & 0.047 \\
208 & octadecane & $593-45-3$ & 0.025 & 0.043 \\
\hline \hline Sum of tentatively identified compounds: & & 251.9 & \\
\hline \hline
\end{tabular}

$1 \mathrm{CAS}=$ Chemical Abstract Service.

2 Average of $3,55 \mathrm{ml}$ TST samples, values listed are estimates. 